\title{
UMA VISÃO PERIEGEMÁTICA SOBRE A ÉCFRASE ${ }^{1}$
}

\section{Paulo Martins ${ }^{*}$ * Professor Livre- A João Adolfo Hansen \\ Docente de \\ Literatura Latina da \\ Universidade de São \\ Paulo. Pesquisador \\ do CNPq. Visiting}

RESUMO: Opero neste artigo três objetivos. Primeiramente, ofereço um panorama sobre a teorização antiga e moderna da écfrase, apresentando elementos que a caracterizam como procedimento retóricopoético a serviço da elocução e da argumentação, ou modernamente a serviço da descrição de uma obra artística - Kunstbeschreibung. Em segundo lugar, apresento como as écfrases, em seu matiz antigo, podem ser apresentadas ora como um elemento da narração que a contém como narrativa - interventive ekphrasis de acordo com Elsner (2002) -, operando especificidades intrínsecas como procedimento contido num gênero continente e a ele subordinado; ora como essas podem apresentar características extrínsecas, como gênero independente, autônomo e isolado em que não estão sujeitas à subordinação argumentativa ou figurativa do gênero, já que são self-standing. O terceiro objetivo, corolário dos dois iniciais, é extrair da observação desses dois tipos de écfrase aquela que serve a um gênero - a que chamo hipotática

\footnotetext{
${ }^{1}$ Este artigo está baseado na estrutura do minicurso "Visualidades Antigas: Pintura, escultura e poesia entre gregos e romanos", ministrado junto ao CEIA - Centro de Estudos Interdisciplinares da Antiguidade da Universidade Federal Fluminense, UFF na XVI Jornada de Estudos da Antiguidade "Redes, Espaços e Fronteiras" em março de 2016; reapresentado na FCLAr da Universidade Estadual Paulista "Júlio de Mesquita Filho" - UNESP em dezembro de 2016, sob o título de Caminhos e Descaminhos da Écfrase; revisto no minicurso "Um olhar Periegético sobre a Écfrase", ministrado junto ao Programa de Pós-Graduação em Letras da Universidade Federal de Ouro Preto - UFOP entre Janeiro e Fevereiro de 2017 e no minicurso "Um olhar periegemático sobre a Écfrase” em março de 2017, sob os auspícios do PPG de Filosofia do IFCS e do PROAERA da Universidade Federal do Rio de Janeiro - UFRJ. Aproveito para agradecer aos professores Manuel Rolph Cabeceiras, Fábio Paifer Cairolli e Beethoven Alvarez da UFF, aos professores João Batista de Toledo Prado e Márcio Thamos da UNESP, assim como aos professores Alexandre Agnolon e Fábio Farvesani da UFOP, Tatiana Oliveira Ribeiro e Henrique Fortuna Cairus da UFRJ, a calorosa recepção, em Niterói, Araraquara e Mariana, e Rio de Janeiro respectivamente.
}

Fellow na Yale

University (2013-14)

e Visiting Professor no King's College

London (2012). 
- e aquela que pode ser entendida como gênero - a que nomeio como paratática -, como suas séries históricas, dependentes de um gênero que as contenha, ou dele independentes, engendram sentidos que podem ser articulados e aferidos a partir de um todo unificador que pode ser, por exemplo, a série de escudos (Homero, Hesíodo, Virgílio, Sílio Itálico) ou a série de descrições presentes numa coleção de écfrases, imagines ou cikóves, (de Filóstrato, o velho e o jovem, e Calístrato) que devem ser observadas em conjunto a formar um todo. Em ambos os casos, uma

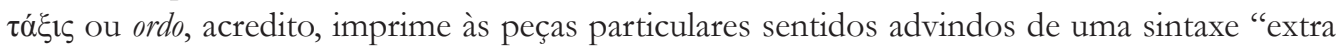
ou intragenérica", que lhes confere sentido próprio.

PALAVRAS-CHAVE: visualidade; écfrase; enargia; progymnásmata; retórica; poética.

\section{A PERIEGEMATIC GAZE ON EKPHRASIS}

ABSTRACT: This article has three objectives. First, I will offer an overview of both ancient and modern theorizations of ekphrasis, presenting elements that characterize it as a rhetoricalpoetical procedure that is at the service of both style and argumentation, and, nowadays, at the service of the description of a work of art - Kunstbeschreibung. Secondly, I will show how the ekphrases, from the perspective of ancient texts, may be presented either as an element of the narration, a procedure that is subordinate to another discursive genre - interventive ekphrasis, according to Elsner (2002) -, or as a procedure that has intrinsic characteristics as an independent, autonomous and isolated genre, which is not subject to argumentative or figurative aspects of another genre, and therefore is "self-standing". The third objective, corollary of the previous ones, is to distinguish from these two types of ekphrasis: one which serves a genre - that I call hypotactic - and another that can be understood as a genre - that I call paratactic. As historical series, either independent or dependent of a genre that includes it, both types of ekphrasis engender meanings that can be articulated and verified in paradigms, such as the series of shields (Homer, Hesiod, Virgil, Silius Italicus) or a series of descriptions in a collection of ekphraseis imagines or eikóves (of Philostratus, both the Elder and the Younger, and Callistratus) - that can be seen as a genre in its own right.

KEYWORDS: Visuality; ekphrasis; enargeia; progymnasmata; rhetoric; poetic.

\section{ConsideraÇões Gerais}

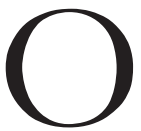

termo écfrase, tendo em vista os textos supérstites, é utilizado pela primeira vez como mecanismo ou procedimento retórico-poético por um Théon, talvez Hélio Teão, professor de Retórica, que teria vivido entre a época de Augusto e o estabelecimento da segunda sofística. ${ }^{2}$ Obviamente a referência do rétor ao termo longe de determinar o início de um uso pragmático, decalcado no conhecimento doutrinário, apenas

\footnotetext{
${ }^{2}$ Falando da datação dos Progymnasmata de Hélio Teão, Kennedy (2003, p. 1) informa: "It is the consensus of scholarly opinion that it is, in any event, the earliest surviving work on exercises in composition, certainly written sometime between the Augustan period and the flowering of the Second Sophistic in
} 
indica que, a partir desse momento, falar de écfrase na Roma e na Grécia do período passa a ser algo corrente nas escolas de retórica, como terminologia, metalinguagem conhecida, logo próxima para autoridades que compõem textos e corriqueiro para aqueles que com esses se deleitam.

Esse recorte temporal ainda assim merece uma avaliação. Mesmo que o termo tenha surgido, como uso técnico, nas escolas de Retórica entre o I séc a.C. e o II séc. d.C., as referências práticas do mecanismo ou procedimento da écfrase apontam não para uma

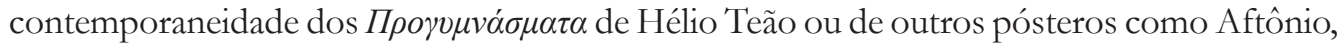
Ps.-Hermógenes, Nicolau, ou mesmo, dos praeexercitamina latinos, como os de Prisciano, mas para seu passado, dado que entre os diversos exemplos que nos são apresentados nestes exercícios $^{3}$ e nos demais posteriores sobre a écfrase especificamente têm-se as autoridades de Homero, Heródoto, Tucídides e outras, isto é, autores que pertencem ao passado desses rétores. Esse tipo de referência, me parece, coaduna-se essencialmente com o caráter didático dos $\pi \rho \gamma \mu \nu \alpha \alpha \sigma \mu \alpha \tau \alpha$ em geral, afinal não há melhor exemplo do que aqueles consagrados por textos amplamente divulgados de autores, digamos, modelares ou exemplares, em seus gêneros. Assim, embora Homero, ${ }^{4}$ Heródoto, ${ }^{5}$ Eurípides, ${ }^{6}$ Tucídides, ${ }^{7}$ Apolônio de Rodes, ${ }^{8}$ Teócrito, ${ }^{9} \mathrm{Mosco}^{10}$ ou Catulo ${ }^{11}$ não tenham tido acesso à écfrase, como aparato técnico-

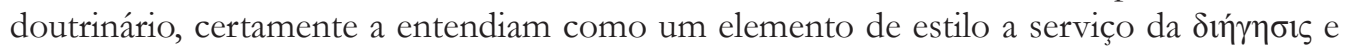
nela contido, em primeira instância.

Outra possibilidade que deve ser observada, em segunda instância, é uma outra vertente ecfrástica, isto é, écfrase como espécie ou gênero poético, singular e não hexamétrico - para não confundirmos com as primeiras ocorrências interventivas (homéricas) ou hipotáticas. Explico: Tem-se, pelo menos desde o séc. VI a.C., um tipo de epigrama que acompanhava esculturas e relevos em suas bases, descrevendo seus conteúdos como forma complementar de linguagem. Tais epigramas foram retomados no período helenístico como produção poética independente, se autonomizando. Eram, portanto, ${ }^{12}$ originariamente, breves legendas que se aplicavam em "traduzir" estátuas, de acordo com Elsner, ${ }^{13}$ belas e enigmáticas,

the second century after Christ, and it shows the system of instruction still in a stage of experiment and development". Vale lembrar que o nome segunda sofística é cunhado por Filóstrato, o velho.

${ }^{3}$ Theon, Prog. 118-120.

${ }^{4}$ Hom., Il., 18.478-608 (o escudo de Aquiles); Hom., Od. 7. 81-136 (o palácio de Alcino). Ver Martins (2013, p. 41-46).

${ }^{5}$ Her., 2.76; 71; 68.

${ }^{6}$ E., Ion. 1102-33.

${ }^{7}$ Th. 2. $74-76$ (cerco de Plateia); 2.49 (a peste).

${ }^{8}$ A.R., 1.730-68 (o manto de Jasão).

${ }^{9}$ Theoc., Idyll 1. 27-60 (o kissubion). Cf. Nogueira (2012, p. 87-94); Payne (2001, p. 263-87).

${ }^{10}$ Mosch., Eur. 37-62. (o cesto de Europa). Cf. Harden (2011, p. 87-105). Costa e Silva (2016, p. 115-29).

${ }^{11}$ Catull, 64 (a manta de Tétis).

${ }^{12}$ Goldhill (2007, p. 1-2).

${ }^{13}$ Elsner (2003, p. 3). 
chamadas кópor e кópal, que, com o passar do tempo, delas se dissociaram, tornando-se, talvez, formas poéticas mais enigmáticas do que as próprias estátuas com seus respectivos textos explicativos, por assim dizer. Esse tipo de écfrase descortina uma espécie singular de observador. Simon Goldhill, ao tratar contrastivamente das "forms of attention" para a écfrase, nota que o observador nos epigramas ecfrásticos está silente e transfixado num enigma que se lhe é apresentado. Mais do que isso, penso eu, por não ser um gênero poético narrativo, o observador confunde-se com os enunciatários, nós leitores, que estamos dedicados a decifrar a poesia, a decodificá-la. Tomemos um epigrama ecfrástico cuja "didascália" o contextualiza: "Tício cravejado de flechas por Apolo e Ártemis, pois ousou fazer violência contra a mãe de ambos, Leto":

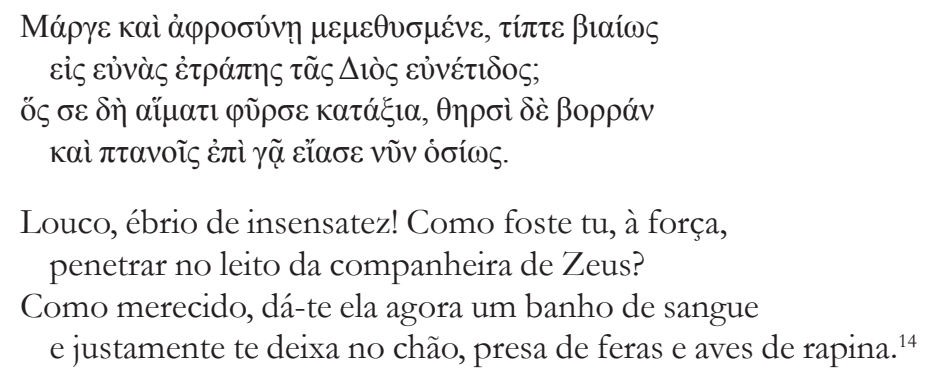

Assim o leitor do epigrama e espectador da estátua são os mesmos, os mesmos olhos que leem são os que observam imagem e num ato contínuo movem os olhos de cima para baixo e de baixo para cima, marcando em si a intersecção das linguagens operadas no processo de leitura da esquerda para a direita. Em certa medida, pode-se associar este movimento de olhos ao caráter periegemático da écfrase visto que dinamiza o olhar, buscando a interação entre o escrito e o visto, ainda que estejamos diante de uma $\phi \alpha v \vartheta \alpha \sigma i ́ \alpha$.

Já na écfrase interventiva e hipotática épica, narrativo-histórica, ou mesmo, dramática o observador está tomado por um espanto, diria eu "em choque", diante daquilo que lhe é apresentado, e nós, lhe/o assistimos silentemente. Penso aqui em Odisseu defronte aos portais do palácio de Alcino ou Eneias diante das pinturas do templo de Juno, ambos estão num momento de reflexão, acabam de sair de uma tempestade, o primeiro como náufrago, o segundo como quem cumpre um destino. Ambos estão num "interpretative moment", 15 num flash de reconhecimento. O primeiro, Odisseu:

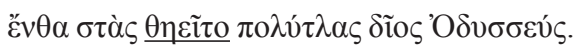

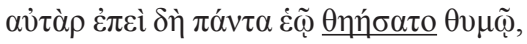

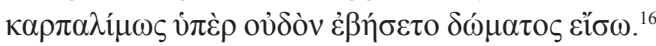

\footnotetext{
${ }^{14}$ AP 3.14. Tradução de Carlos A. Martins de Jesus.

${ }^{15}$ Goldhill (2012, p. 104).

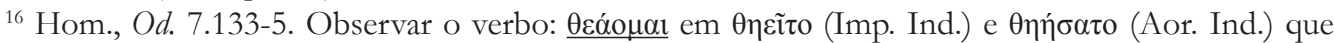

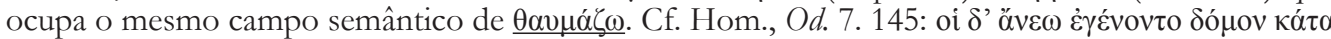

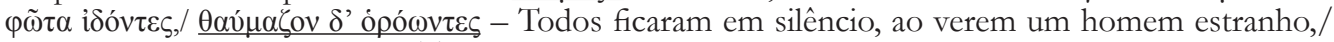
e maravilhavam-se ao olhá-lo. Todas as traduções de Homero aqui apresentadas são de Frederico Lourenço.
} 
Ali, de pé, se maravilhou o sofredor e divino Ulisses. Mas depois de com tudo ter se admirado no coração, transpôs rapidamente a soleira e entrou no palácio.

O segundo, Eneias:

namque sub ingenti lustrat dum singula templo reginam opperiens, dum quae fortuna sit urbi artificumque manus inter se operumque laborem miratur, uidet Iliacas ex ordine pugnas bellaque iam fama totum uulgata per orbem, (...) ... atque animum pictura pascit inani multa gemens, largoque umectat flumine uultum. ${ }^{17}$

pois, quando a máquina ingente do templo de perto admirava, coisa por coisa, a esperar pela nobre rainha; a fortuna rara daquela cidade, o primor dos trabalhos já feitos e a agilidade dos hábeis artífices, nota as batalhas já divulgadas pelo orbe, da terra de Troia destruída.

(...)

... e enquanto a alma apascenta com a vista de vãs pinturas, soluça, de prantos o rosto banhando. ${ }^{18}$

Seja qual for o tipo de observador, posso fazer um paralelo entre a desvinculação dos epigramas de suas estátuas com a desvinculação das écfrases hipotáticas de seus gêneros continentes. Diz Sandrine Dubel: "Il semble que l'on assiste à une construction progressive de l'autonomie da la description, acquise avec l'ekphrasis."19 Dessa forma, é seguro dizer que transistoricamente a écfrase tende a ser autônoma e independente e, nós, recepção, passamos cada vez mais a ter uma posição mais importante diante dela, pois quanto menos a écfrase se subordina ao gênero, mais está subordinada ao leitor uma vez que, se, de um lado, a sua subordinação é alimentada pelo sentido "do todo" da narração, de outro lado, o seu isolamento ou autonomia repassa essa função ao enunciatário, ao leitor, que se torna um interprete mais ativo nesta operação. Se, diante destas ilações, ainda entendermos que a descrição vívida, a écfrase, é definitivamente um elemento da narração de matiz descritivo que ganha autonomia como gênero específico, podemos negar peremptoriamente boa parte dos narratologistas contemporâneos que minimizam a importância da descrição ou, pelo menos, lhe atribuem absoluta relação ancilar com a narração ou subserviente a ela. Nesse sentido, Fowler afirma que:

\footnotetext{
${ }^{17}$ Virg., A. 1.453-7 ... 464-5.

${ }_{18}$ Todas as traduções da Eneida neste trabalho são de Carlos Alberto Nunes.

${ }^{19}$ Dubel (1997, p. 254).
} 
as Genette noted in his article on the 'Boundaries (sic) ${ }^{20}$ of Narrative, ${ }^{21}$ description in general is secondary, is 'ancilla narrationis, the ever-necessary, ever-submissive, never-emancipated slave'. Set-piece description is not even in any real sense necessary. Hence controversial nature of description and the strong antipathy to it which critics from Lessing to Lukacs have often shown. ${ }^{22}$

Assim, mesmo que, à época de Homero, Heródoto, Eurípides, Tucídides ou Apolônio de Rodes e Teócrito entre outros no caso de écfrases como procedimento contido num gênero - hipotáticas -, ou como gênero poético helenístico independente - paratáticas -, a nomeação do procedimento retórico-poético ainda não tivesse sido delimitada com uma terminologia ou metalinguagem precisa - talvez sequer houvesse tal preocupação -, é certo que a prática discursiva já havia sido implementada por estas mesmas auctoritates pelo menos no âmbito narrativo ou dramático. Assim supor um anacronismo terminológico no que se refere à écfrase é absolutamente pouco importante. ${ }^{23}$ Por outro lado, Hansen, em recente e basilar ensaio sobre as categorias epidíticas da écfrase, contribui para demonstrar que a utilização de critérios que generalizaram o uso particular da écfrase - descrição de obra de arte - em chave desistoricizada, ampliando seu uso a inúmeras áreas do conhecimento, desqualifica o procedimento que deve ser entendido sim na longa duração do conceito de base retórico-poética -, desnudando, pois, pontos de contato transistóricos, muita vez, descontínuos, ${ }^{24}$ de sua aplicação com base na emulação entre autoridades poético-retóricas. ${ }^{25}$ Sinaliza por fim:

Suponho que é mais pertinente observar os processos de longa duração de transmissão de técnicas e modelos e das apropriações descontínuas deles. Com isso, pode-se demonstrar que autores situados em pontos diversos do tempo escolhem suas próprias amizades e inimizades artísticas e que, num mesmo período que nossas histórias literárias e histórias da arte classificam unitariamente com etiquetas dedutivas e evolutivas (...), encontramos efetivamente várias durações artísticas simultâneas e suas maneiras de conceber e produzir as artes e seus estilos, por vezes como um contínuo de emulações retrospectivas, por vezes como emulações descontínuas. ${ }^{26}$

\footnotetext{
${ }^{20}$ O título original é "Frontiers" e não "Boundaries”, na tradução inglesa de 1982, como nos apresenta Fowler.

${ }^{21}$ Genette (1982, p. 127-44).

${ }^{22}$ Fowler (1991, p. 26).

${ }^{23}$ Martins (2014, p. 201-1).

${ }^{24}$ Kossovitch (2000, p. 303-39).

${ }^{25}$ Hansen (2006, p. 87).

${ }^{26}$ Hansen (2006, p. 87).
} 
Diante disso, conquanto observemos o mecanismo da écfrase nomeado inadvertida ou equivocadamente em visada projetiva, mas nele detectemos sua série histórica, recuperando características essenciais na longa duração, pontuando seus êmulos, então defendo que a terminologia possa ser reaproveitada retroativamente, reavivada transistoricamente, o que, em nosso caso, significa aplicá-la indistintamente a Homero ou a Apolônio de Rodes; a Filóstrato ou a Paulo Silenciário, dando assim autoridade às écfrases interventivas ou bipotáticas; ou às écfrases autônomas ou paratáticas; ou às pragmáticas ou doutrinárias.

\section{NARrar E DESCREVER}

É inegável que a língua latina deu à écfrase o nome descriptio. ${ }^{27} \mathrm{~A}$ rigor o LSJ apresenta

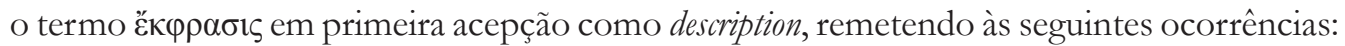
D.H., Rh. 10.17; Luc. Hist. Conscr. 20; Hermog., Prog. 10 e Aphth. Prog. $12 .{ }^{28} \mathrm{Já}_{\text {Baillyy }}^{29}$ apenas indica o fato de ser um título de obra, description, no mais segue os mesmos exemplos do LSJ.

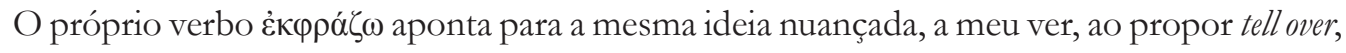
recount (A., Pr. 950 e E., HF 1119), ${ }^{30}$ ou denote (Plu. 2.24a), além de apresentar explicitamente em segunda acepção: describe (Hermog. Prog 10; Prog. 2.4 e Men. Rh, p. 3735$)^{31}$ ou a curiosa possibilidade em Demetr., Eloc. 165: express ornately. Enquanto Bailly assinala: expliquer tout an long, exposer en détail ou d'ou décrire (Hermog., Prog 48), ou designer (Plu., M. 24a). Tal observação nos leva a crer - e isto já é algo posto - que não há como apartar a ideia de descrição da própria condição de narratividade, isto é, a descrição é parte inseparável da narração de maneira que a écfrase é sempre narrativa.

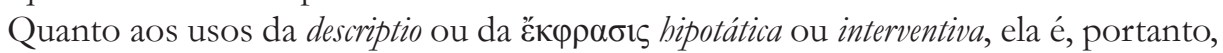
um parêntesis na estrutura da narração, uma suspenção de seu vetor progressivo, um desvio ou um retardamento do fluxo textual, uma antecipação de eventos ou uma recuperação de elementos que compõem o $\mu \tilde{0} \theta$ os, a fim de estruturar ou reestruturar a narração, temporal, temática ou figurativamente numa sequência necessária e útil. ${ }^{32}$ Características essas que, parece-me, aproximam-na da própria ideia de digressio ou egressio, digressão, em conformidade com as lições de Cícero e de Quintiliano. ${ }^{33}$

\footnotetext{
${ }^{27}$ Cf. a tradução de Prisciano a Ps.-Hermógenes.

${ }^{28}$ LSJ (1977, p. 526).

${ }^{29}$ Bailly (1984, p. 636).

${ }^{30}$ Bailly (1984, p. 636).

${ }^{31}$ LSJ $(1977$, p. 526).

32 Cf. Elsner (2002, p. 4): "In narratological terms, Homer's Shield - a pause in the narrative that allows other kinds of narratives to figure both within the main text and bracketed apart from it, an implicit meditation on totality of the text within which it constitutes but a small episode, and yet a material item with its own significant part to play in the Iliad's main story - fundamentally prefigures the role of ekphrasis in the later tradition."

${ }^{33}$ Cic., Brut. 322; Quint., Inst. 4.2.19. Cf. Canter (1931, p. 351); Martins (2013, p. 72-6).
} 
Em Eurípides, no Íon, ${ }^{34}$ ocorre algo curioso, pois que estamos diante de uma écfrase bipotática que atua não na narração continente, mas no drama continente, numa tragédia, articulando-se, pois, no enredo dramático como síntese da ordem que se refaz na tragédia com seu desenlace, de forma que as tapeçarias da tenda que desenham o universo das estrelas em constante ordem representam a própria ordem da terra que está sendo reestabelecida com o final da tragédia.

Ruth Webb, por sua vez, muito precisamente alerta que distinção entre descrição (entendida como representação de objetos estáticos) e narração (como representação de ações ou eventos) é algo absolutamente moderno. Defende que a écfrase na retórica antiga "fell somewhere between these two categories, and was often a vivid and detailed narration of events". ${ }^{35}$ Ainda propõe que modernamente há a ideia de que suspensão ou interrupção da narração por intervenção da écfrase retira dela o que possui de movimento. Isto não deve prosperar para os textos antigos, afinal "ekphrasis was not defined as an interruption to the temporal flow of a surrounding narrative, but usually incorporated some temporal progression itself." $36 \mathrm{Na}$ verdade, creio que na écfrase interventiva trabalha-se com dois movimentos: a) o movimento do fluxo da narração continente e b) o fluxo da própria "narrativa" ecfrástica. Enquanto o primeiro movimento, isto é, o movimento do fluxo da narração continente tem de ser suspenso obrigatoriamente pela intervenção da écfrase - uma interventive ekphrasis -, o próprio moto da écfrase passa a intervir e nela mesma um movimento passa a ser representado no cerne dessa écfrase hipotática.

Ainda mesmo quando estamos diante de uma écfrase autônoma - self-standing ekphrrasis podemos observar uma dinâmica própria intervindo no interior da écfrase. Linguisticamente o uso de elementos dêicticos, pronomes e advérbios de lugar e tempo, ${ }^{37}$ fazem a écfrase ter um movimento sui generis, o enunciador ecfrástico de uma obra de arte, portanto, ignora a natureza estática e espacial da pintura, do relevo, do mosaico ou da tapeçaria e relata "os acontecimentos descritos como se estivessem se desdobrando no tempo", ${ }^{38}$ como que imprimindo à imago o envolvimento emocional ou patético do descritor, do enunciador ecfrástico. Essa dinâmica mantém uma estreita relação com a ideia de periegese que trabalharemos adiante.

Alguns poderão propor que a écfrase numa narração é um lugar-comum necessário, entretanto, Ps.-Hermógenes, por exemplo, ao tratar dela, narração, ensina que o escudo de

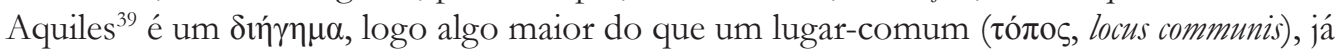

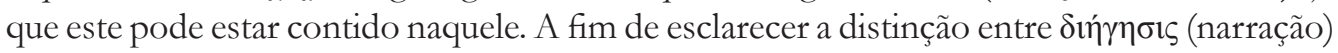

\footnotetext{
${ }^{34}$ E., Ion 1102-33.

${ }^{35}$ Webb (1999, p. 64).

${ }^{36}$ Webb (1999, p. 64).

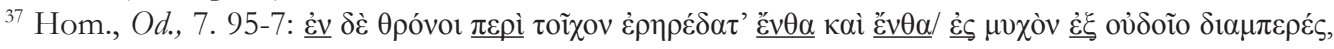

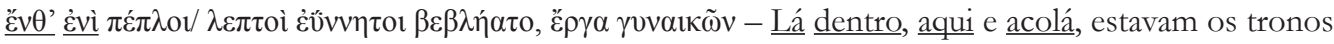

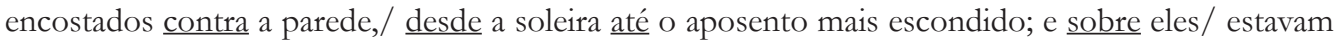
mantas delicadas, bem tecidas: trabalhos de mulher.

${ }^{38}$ Webb (1999, p. 64).

${ }^{39}$ Hom., Il., 18.478-608.
} 
e $\delta$ ị́ $\eta \mu \alpha$ (narrativa), ${ }^{40}$ o rétor nos afiança que a diferença entre uma e outro é a mesma

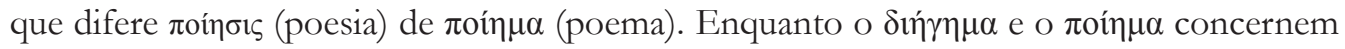

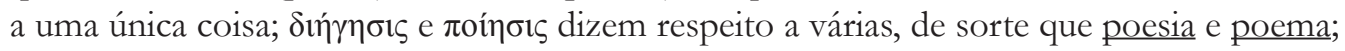
narração e narrativa são pares análogos. A narração e a poesia são gerais, da mesma forma que a narrativa e o poema são particulares.

Ensina Ps.-Hermógenes:

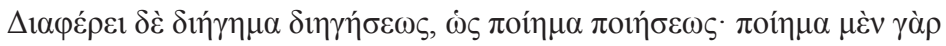

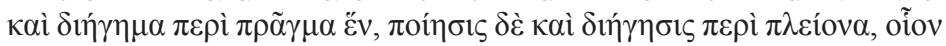

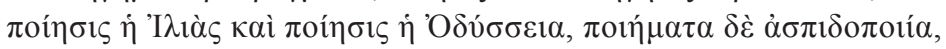

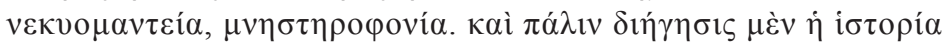

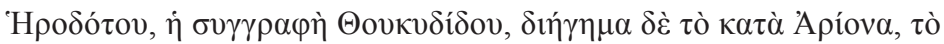
$\kappa \alpha \tau \grave{\alpha} \mathrm{A} \lambda \kappa \mu \alpha \dot{\omega} \omega v \alpha .{ }^{41}$

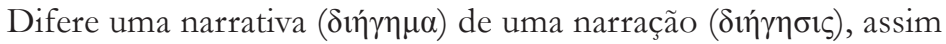

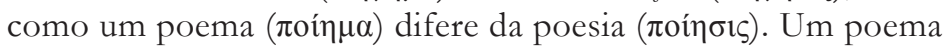
( $\pi$ oí $\mu \alpha)$ e uma narrativa $(\delta i \eta ́ \gamma \eta \mu \alpha)$ dizem respeito a uma única peça, enquanto a poesia e a narração, a muitas; toda a Ilíada e toda a Odisseia, cada qual é uma poesia, enquanto a "Fabricação do Escudo"42, a "Nekyia" e a "Morte dos pretendentes" $"$ são poemas (

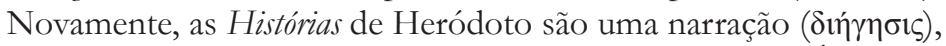
assim como o é a de Tucídides, entretanto as histórias de Árion em

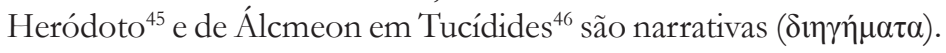

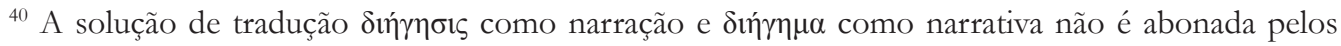
dicionários, entretanto vem referendada por Kennedy (2003, p. 75), quando observa esta exata passagem de Hermógenes e ao qual sigo neste artigo.

${ }^{41}$ Hermog., Prog., 2.4-2.10. Cf. Martinho (2010, p. 283): "A diferenciação de diégema e diégesis lê-se não só no Ps.-Hermog. (4.9-15 R), mas em outros autores de progymnásmata, a saber: em Aftônio (2.16-8 R) e Nicolau (11.16-12.6 F) e, daí, em comentadores de Aftônio, a saber: nos Com. 1 (RG 2, 13.6-10) e 2 (RG 2, 580.6-7) e em Doxópatro (RG 2, 198.17-199.3). Demais, esses argumentam de modo semelhante, ou melhor, propõem três explicações, assim resumidas por Nicolau e também por Doxópatro: $1^{a}$ diégesis é exposição de controvérsias no tribunal feita para o proveito do orador, e diégema, enunciação do que se examinou ou ocorreu; $2^{\mathrm{a}}$ diégesis é exposição de casos verdadeiros, e diégema, de

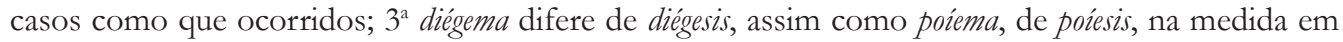
que diégema e poíema respeitam a um único caso, e diégesis e poíesis, a mais de um; por exemplo, a obra toda da Iliada é poíesis, e o episódio da confecção do escudo, poiema. Em particular, a $3^{a}$ é a explicação do Ps.-Hermog. e, daí, de Aftônio".

${ }^{42}$ Hom., Il. 18.478-608.

${ }^{43}$ Hom., Od., 11.

${ }^{44}$ Hom., Od., 22.

${ }^{45}$ Hdt., 1.23.

${ }^{46}$ Th. 2.102.
} 


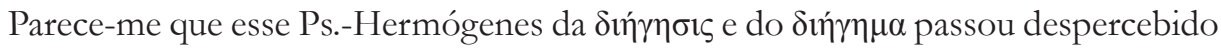
entre muitos estudiosos contemporâneos. Quando o rétor propôs que o "escudo de Aquiles" é uma narrativa, assoma à ideia de écfrase um elemento importante, dado que esta é também um $\delta$ ı́ $\gamma \eta \mu \alpha$, narrativa, mas ainda não é uma narração, $\delta$ ı́ $\gamma \eta \sigma \iota$. $^{47}$ Isto implica algo interessante no caso de Homero, porquanto, se o escudo de Aquiles é um episódio, é um elemento que compõe a narração, contribuindo com o desenvolvimento do $\mu \tilde{v} \theta \mathrm{o}_{\varsigma}{ }^{48}{ }^{4}$ da trama, de sorte que se torna um elemento que afeta a progressão temporal que distingue a narração da narrativa. ${ }^{49}$ Elsner afirma que, embora a primeira écfrase na literatura antiga apresente-se como uma pausa da narração em que o texto se desvia de sua obsessão pelo desdobramento da guerra para uma outra visão, a saber, cenas de paz, festividades, agricultura, canções e danças, esse microcosmo na verdade enfatiza o que a Ilíada não é, ou aquilo que teria sido se Páris não tivesse raptado Helena ou se os troianos a tivessem devolvido aos gregos, tudo isto ironicamente gravado nas armas que Aquiles usará para demonstrar sua ira. ${ }^{50}$

O mesmo, e até mais claramente, ocorre na écfrase do palácio de Alcino no canto 7 da Odisseia, que funciona como um elo de ligação entre dois mundos muito distantes: o país dos Feácios, um mundo imaginário, e Ítaca, um mundo concreto da realidade vivida do herói, alvo de seu vó $\tau \tau$ os. ${ }^{51}$ A esse tipo de écfrase, isto é, o escudo e o palácio na poesia homérica, modernamente, deu-se o nome de interventive ekphrasis, ${ }^{52}$ guardando, pois, seu lugar

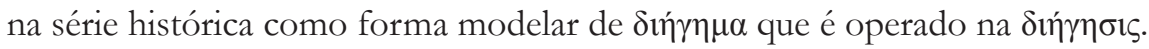

Webb, entretanto, valendo-se de Nicolau e não observando a distinção do tratamento

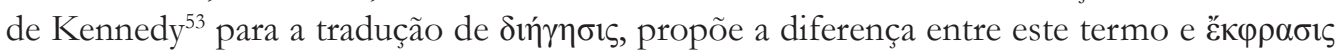
para demarcar pontos que podem fazer distinção entre "narração" e écfrase. Enquanto a segunda obrigatoriamente tem vividez (غ่vó $\rho \gamma \varepsilon 1 \alpha$ ), a primeira não. Esclarece, contudo, que deste entendimento nasce uma questão, a saber, quando a narrativa é suficientemente vívida,

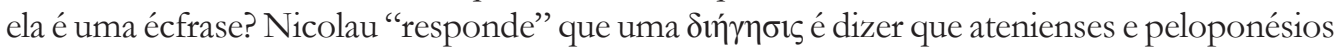
foram à guerra; já é uma écfrase dizer que cada qual foi à guerra de tal e tal maneira, segundo suas preparações e equipagem específicas. ${ }^{54}$

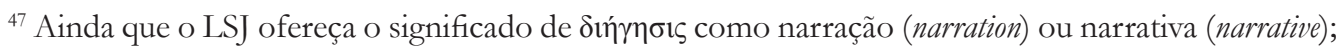

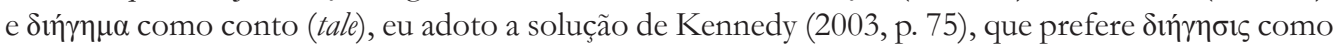
narration e $\delta i \eta ́ \gamma \eta \mu \alpha$ como narrative.

${ }^{48}$ Cf. Hansen (2006, p. 87): "não se pode isolar a descrição do escudo da ação épica do poema. Como se sabe, Pátroclo é morto por Heitor, no canto 17; a cólera de Aquiles é imensa e sua mãe, Tétis, pede o escudo a Hefesto. Lessing afirmou que Homero não pinta o escudo como objeto autônomo ou terminado, mas como elemento descritivo que amplifica o epos da ação colérica do herói”.

${ }^{49}$ Martins (2013, p. 32-47).

${ }^{50}$ Elsner (2002, p. 4).

${ }^{51}$ Martins (2014, p. 28-33).

${ }^{52}$ Elsner (2002, p. 3-9); Harloe (2007, p. 237); Nicolai (2009, p. 41); Zeitlin (2013, p. 19) e Squire (2015, p. 9).

${ }^{53}$ Kennedy (2003, p. 75).

${ }^{54} \operatorname{Webb}(2009$, p. $70-1)$.
} 


\section{A QUE VEIO A ÉCFRASE?}

É justamente a proposta de Ps.-Hermógenes de écfrase como $\delta ı ́ \gamma \eta \mu \alpha$, contida numa $\delta ı \mid \eta \gamma \eta \sigma \varsigma s$, que fundamenta, em certa medida, penso eu, a independência adquirida pela écfrase rumo à sua transformação em gênero, ou à sua autonomização como gênero (self-standing ekphrasis) como encontramos nos Livros II e III da Antologia Palatina, nos dois Filóstratos e em Calístrato, e até mesmo mais tardiamente em Paulo Silenciário, ${ }^{55}$ afora na modernidade com Keats ou Rilke, ${ }^{56}$ dado que a écfrase abandonaria seu caráter particular e adquiriria suas características gerais, genéricas e independentes. Teria a écfrase, assim, abandonado sua condição de poema, transformando-se em poesia ou abandonado a condição de narrativa, transformando-se em narração. Vale dizer que segundo grande parte dos estudiosos a écfrase autônoma, ou genérica, ou paratática, como pretendo denominar neste trabalho, teria nascido a partir da dissociação de certa epigrafia (muita vez dísticos elegíacos) de bases de estátuas no mundo arcaico grego que deram origem no mundo helenístico aos epigramas ecfrásticos, como vimos, e não somente a partir da cisão entre o gênero continente ( $\delta$ í $\gamma \eta \sigma \iota \varsigma$ - narração) e o procedimento narrativo contido ( $\delta \eta \gamma_{\gamma} \eta \alpha$ - narrativa). Certo é, porém, que, por exemplo, ao explorar visualidades, alguns poetas, como Keats e Rilke, executam um mesmo projeto antológico dos Filóstratos e de Calístrato, reunindo écfrases autônomas ou paratáticas.

Sob a perspectiva de teorias narratológicas, Fowler ${ }^{57}$ propôs uma excelente síntese sobre a descrição partindo das críticas encetadas contra essa desde muito tempo. Por exemplo, de acordo com Bal à descrição corresponderia um nível da narração em que nada acontece na estória. Assim o enredo não avança. A descrição seria apenas uma pausa dessa narração. ${ }^{58}$ Genette, por seu turno, a toma como secundária, uma ancilla narrationis, ainda que sempre necessária, ela é ainda sempre submissa e jamais um escravo-liberto. ${ }^{59}$ Lukacs afirma que "o poeta épico real não descreve objetos, mas expõe suas funções na malha dos destinos humanos, apresentando as coisas apenas como desempenham um papel nos destinos, ações e paixões dos homens" ${ }^{60}$ Concluindo, posso dizer que a narração fala sobre as pessoas e a descrição trabalha com as coisas. Ainda que observemos certa acerbidade dessa crítica, Bal aponta para uma função da descrição: "In Homer, pauses are avoided. Often descriptions of objects are replaced by retroversions, which also have a slowing-down effect, but still replace the broken line of time by another temporal sequence." 61

Recentemente, Soares, ao tratar da écfrase entre os historiadores gregos, apresenta um excelente estado da questão, ainda que este esteja longe da amplitude aqui pretendida - lá o

\footnotetext{
${ }^{55}$ Becker (1837, p. 3-48); Whitby (1985, p. 215-28); Macrides, Magdalino (1988, p. 47-88).

${ }^{56}$ Ode sobre uma urna grega e Torso arcaico de Apolo, respectivamente, são bons exemplos.

${ }^{57}$ Fowler (1991, p. 26).

${ }^{58} \mathrm{Bal}(2009$, p. 106-7).

${ }^{59}$ Genette (1982, p. 134).

${ }^{60}$ Lukacs (1978, p. 137).

${ }^{61} \mathrm{Bal}$ (2009, p. 106-7).
} 
autor aplica-se apenas à historiografia antiga - situa a écfrase, a enargia e seu desenvolvimento diacrônico, aplicando-lhes função argumentativa:

Os historiadores antigos (...) tinham por hábito conferir assertividade e autoridade às suas narrativas históricas insuflando-lhes vividez pictórica, de modo a gerar impacto emocional e visual na mente dos ouvintes ou leitores. Este processo é frequentemente mencionado nos antigos manuais de retórica sob a designação de enargeia, sendo esta a alma da ekphrasis, e era comum não só entre historiadores como entre poetas e oradores. É da epopeia homérica que nos vêm os exemplos mais antigos. Ora, no caso da historiografia, longe de minar a confiança do leitor, a enargeia contribuía para aumentar a credibilidade do relato, na medida em que aproximava a observação indireta do leitor da observação direta (autopsia) do historiador ou da testemunha. ${ }^{62}$

Soares acrescenta, a meu ver, à dicotomia narração-narrativa que defendo com base em Ps.-Hermógenes critério probatório-argumentativo ao mecanismo retórico-poético da écfrase, logo afastando a compreensão romântica que lhe assenta, à écfrase, etiqueta equivocada de prática "atentatória da objetividade e seriedade do trabalho do historiador." Nesse sentido Hansen propõe: "como exercício de eloquência, a ekphrasis é uma pragmática: evidencia justamente a habilidade do orador que espanta a audiência com a narração da falsa fictio tornando o efeito provável porque sua imaginação é alimentada pelos topoi da memória partilhada." ${ }^{63}$ Logo o efeito de prova pretendido pelos historiadores gregos em nada difere do mesmo efeito em narrativas ficcionais pelo simples motivo de serem ambos efeitos.

Outra questão que deve ser observada é a estreita relação entre écfrase e enargia. Esta muito bem elucidada pelo estudioso já que, ao mesmo tempo em que demonstra sua estreita relação, admite independência entre ambas, diz que a enargia é característica sine qua non à écfrase, entretanto, pode aquela existir sem esta isoladamente.

É uma das questões neste artigo observar em que medida esta característica

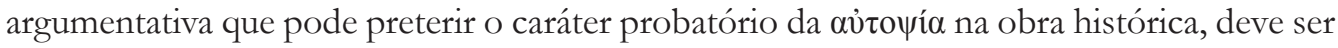
aferida na obra continente de matiz ficcional. Antecipando, creio que o argumento ecfrástico historiográfico é substituído pelo caráter digressivo ecfrástico, fazendo migrar o objetivo do mecanismo retórico-poético do âmbito da invenção para o da elocução, da argumentação (argumentatio) para as virtudes do estilo (uirtus elocutionis). Jaś Elsner, nesse rastro, explica:

the uses of enargeia and sapheneia to summon the fictive object to the reader's eyes can have fundamental and varied effects in relation not only to the specific objects described, but to the larger interpretation of the text in which they appear. ${ }^{64}$

\footnotetext{
${ }^{62}$ Soares (2011, p. 1-2).

${ }^{63}$ Hansen (2006, p. 86).

${ }^{64}$ Elsner (2002, p. 3).
} 
Essa produção de efeito de sentido da écfrase sobre a obra continente, isto é, a figuratividade que incomoda o todo em que está inserida, segundo entendo, resguarda não só virtudes estilísticas - uirtutes elocutionis - como as argumentativas. Nesse sentido, ainda que no texto historiográfico a écfrase seja prova que substitui uma av̉iowía e isto lhe dê um valor argumentativo; na obra de ficção, a figuratividade da imagem descrita - mesmo que não seja probatória - não lhe rapta o mesmo tipo valor, comportando-se em acordo ao dulce et utile horaciano, na medida que o dulce lhe garante o deleite (delectare) textual, produzido por virtudes que lhe emprestam sabor e vividez, enquanto o utile lhe advém do caráter probatório e didático (monere et docere) do texto ecfrástico, que empresta caráter visual ao texto.

\section{OlHar RETROSPECTIVO E VISÃo PROSPECTIVA}

Se pensarmos em écfrases que antecedem à normatização retórica como práxis e em outras que a sucedem, tomando a norma uma baliza possível, é lícito pensar que podemos inicialmente, além das possibilidades da écfrase interventiva e autônoma, operar mais duas categorias históricas: uma pragmática e outra doutrinária. Chamo de écfrase pragmática aquela que seguramente independe de uma doutrina retórica que a regule, a delimite em seu uso e lhe organize os modos. Essa écfrase, assim, deve ser avaliada em acordo com um olhar retrospectivo em que apenas a referência homérica organiza o uso por antecedência histórica de base emulativa. Essas jamais buscariam, por exemplo, suas referências nas $\mu \varepsilon \lambda \dot{\varepsilon} \tau \alpha$ l (declamações), nas $\delta 1 \alpha \lambda \varepsilon_{\varepsilon} \xi \varepsilon 1 \zeta$ (falas menos formais) ou nas $\pi \rho 0 \lambda \alpha \lambda ı \alpha i$ (exercitações), já que isto estabeleceria claramente uma projeção anacrônica. Nesse sentido, parafraseando Italo Calvino ao falar sobre os clássicos, as écfrasespragmáticas são aquelas que chegam até a doutrina da écfrase trazendo consigo marcas das leituras que precederam à sua própria normatização retórica e atrás de si as marcas que deixaram na cultura ou nas culturas que atravessaram. As écfrases pragmáticas, portanto, são aquelas que vem antes de outras écfrases pragmáticas, mas quem lê antes as outras e depois aquela, reconhece nela o seu lugar na genealogia. ${ }^{65}$

Já a écfrase doutrinária é aquela que assenta sua atenção no passado retrospectivo, serial, porém se fia também doutrinariamente no conceito retórico-poético sincrônico ou prospectivo a fim de lhe regular decorosamente um sentido advindo da conceituação precisa, ensinada e transmitida. Ademais compõe o seu conteúdo os das declamações e das composições escolares como bem exemplifica Libânio, ${ }^{66}$ amiúde, a partir dos mesmos

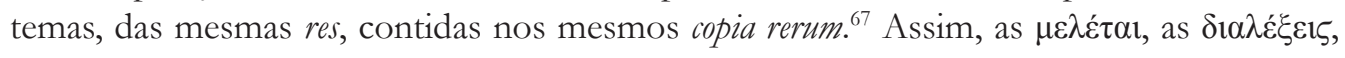

${ }^{65}$ Calvino (1994, p. 11): “Os clássicos são aqueles livros que chegam até nós trazendo consigo as marcas das leituras que precedem a nossa e atrás de si os traços que deixaram na cultura ou nas culturas que atravessaram (ou mais simplesmente na linguagem ou nos costumes)". Calvino (1994, p. 14): "um clássico é um livro que vem antes de outros clássicos; mas quem leu antes os outros e depois lê aquele, reconhece logo o seu lugar na genealogia".

${ }^{66}$ Ver Gibson (2008).

${ }^{67}$ Webb (2009, p. 61-2). 
ou as $\pi \rho 0 \lambda \alpha \lambda \imath \alpha i{ }^{68}$ apresentações pragmático-doutrinais dos sofistas, comprovam a aplicação do conceito tanto nas res como nos uerba, tanto nos conteúdos como nas formas, por assim dizer. Dessa maneira, ao pensarmos as écfrases doutrinárias, como discursos, devemos ter em vista transistoricamente "suas amizades" poético-retóricas, de forma que adquirem camadas precisas de sentido, fundadas historicamente pelos seus usos e isso deve ser legitimado em nossas observações. Sem considerarmos tais camadas desses discursos nos dois vetores retrospectivo e prospectivo - deixaremos de lado camadas que podem revelar outros níveis de compreensibilidade, nascidos da relação entre esses textos e suas recepções diacronicamente.

$\mathrm{Na}$ verdade, a segunda sofística imprime à écfrase manifestamente sua dupla filiação, pragmática e doutrinária, já que ambas apontam para o virtuosismo, para o ecletismo e, principalmente, para a erudição que concentram no discurso produzido lugares da memória cultural partilhada, da pertença comum desse mundo romano-helênico, ou como preferiu dizer P. Veyne, desse império greco-romano. ${ }^{69}$

\section{Hélio TEÃo, AFTôNio, PS.-HERMógenes, NiCOLAU E PRISCIANO}

Partamos, pois, de nosso ponto zero, isto é, o nascimento da prescrição sobre écfrase para que depois nos debrucemos retrospectiva e prospectivamente. As definições a que temos

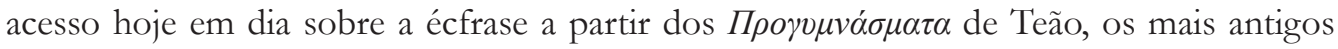
talvez, são praticamente idênticas, entretanto possibilitam a observação de algum elemento inclusivo diferencial, ainda que aparentemente possa parecer pouco significativo. Vejamos.

Tanto Teão como Aftônio apresentam as seguintes definições praticamente idênticas porquanto apenas o advérbio દ̇v $\alpha \rho \tilde{\omega} \varsigma$ apresenta uma alteração de posição, em Teão antes de

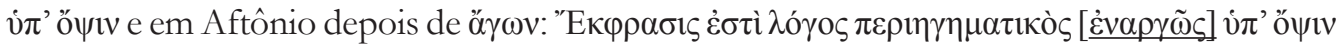

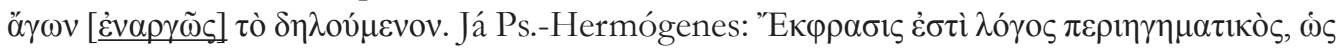

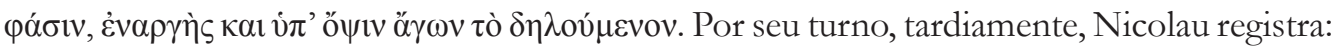

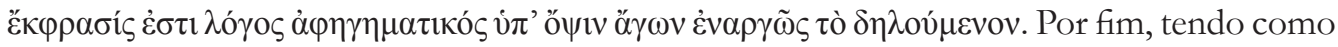
base Ps.-Hermógenes, Prisciano apresenta sua definição latina: Descriptio est oratio colligens et

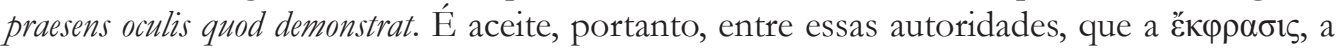
descriptio, é um $\lambda$ ójos, uma oratio, um discurso - em seu senso geral e não genérico a meu

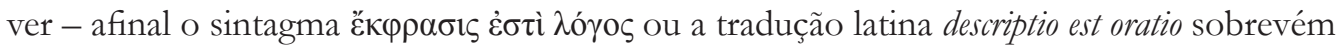
a esses autores.

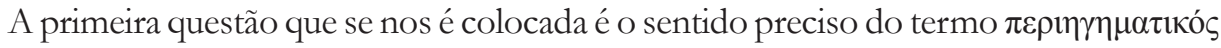
que está presente em Teão, Aftônio e Ps.-Hermógenes, traduzido por Prisciano por colligens e que ressurge em Nicolau permutado por ả

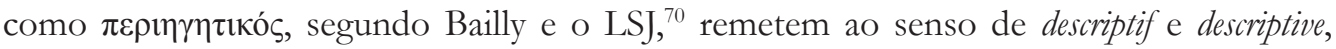
respectivamente, contudo, parece-me que a simples remissão à qualidade da descrição pode lhe intimidar o sentido. O verbo $\pi \varepsilon \rho ı \gamma \varepsilon \dot{\varepsilon} 0 \mu \alpha \iota$ antes de indicar a ideia de descrição, ato

\footnotetext{
${ }^{68}$ Ver Elsner (2009, p. 7-17); Bowie (2009, p. 25-6); Swain (2009, p. 40-1).

${ }^{69}$ Refiro-me ao livro L'Empire gréco-romain. Paris: Éditons du Seuil, 2005.

${ }^{70}$ Bailly (1984, p. 1524); LSJ (1977, p. 1374).
} 
anímico ou abstrato, possui senso físico visto que opera a ideia do conduzir ao redor, como quem cerca algo a fim de que nada que esteja circunscrito por este movimento the escape. Logo a simples descritividade do ato o restringe semanticamente, pois elimina a condição de completude impressa no $\pi \varepsilon \rho \uparrow \gamma \eta \mu \alpha \tau$ cós. É justamente a condução pelo espaço natural e sua exposição realizada pelos geógrafos - penso em Pausânias - que permite que seu

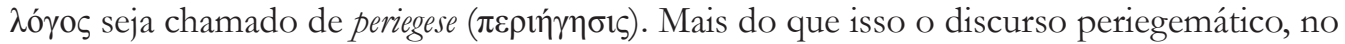
caso, ecfrástico conduz exegeticamente os olhos da mente do interlocutor ao derredor de objetos, e espaços, e gentes, e circunstâncias, e vezes, e máquinas, e pinturas, e esculturas, observados de acordo com os sentidos do hermeneuta, ${ }^{71}$ do sofista, do rétor, ou do poeta que nos conduz pelo $\lambda$ ó $\gamma o c$. A definição, a meu ver, ganha com a aplicação desse adjetivo nesse sentido mais preciso a componente do discurso pormenorizado apontado por Lausberg, mas não suficientemente explicado por ele. ${ }^{72}$ Quase esta mesma ideia pode ser observada em um

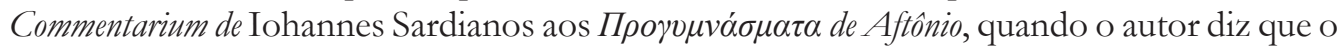
$\lambda o ́ \gamma o \varsigma \pi \varepsilon \rho ı \gamma \eta \mu \alpha \tau$ ı́ó apresenta-se como discurso topográfico no lugar de uma pintura que se oferece detalhadamente como se o autor desse discurso estivesse a caminhar com seu interlocutor pela cidade de Atenas, querendo lhe mostrar tudo na cidade detalhadamente. ${ }^{73}$ O que se depreende do sentindo de $\lambda$ ó denotativo, a descrição pura e simples, "organiz̨ing principle for their descriptions", ${ }^{74}$ de outro lado, seu sentido metafórico, em que podemos entender o processo de composição, como uma

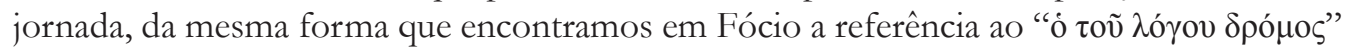
- o curso do discurso $-{ }^{75}$ isto é, ao discurso em progresso.

Quanto à proposta de Nicolau, explicita apenas o que aqui defendo, a saber, a ideia de

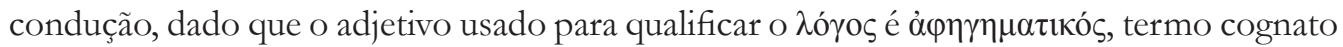
do verbo $\alpha \dot{\varphi} \eta \gamma \varepsilon \dot{\varepsilon} \mu \alpha \mathbf{l}$ cujos significados de acordo com o Bailly são: conduire à partir d'un endroit; marcher en tète à partir d'un point déterminé, p. suite, guider, conduire un troupeau, une colonie, une ambassade, gouverner e em segunda acepção, figurada, raconter du commencement à la fin, exposer

\footnotetext{
${ }^{71}$ Hansen (2006, p. 86): "Na ekphrasis, o narrador se define como intérprete (exegetés) da interpretação que o pintor fez de sua matéria. Assim, geralmente antecipa a exposição das imagens fictícias com a declaração de que as viu diretamente ou que viu uma cópia delas. Esse "como se" é fundamental na ficcionalização da enárgeia, sendo necessário observar que o autor finge transferir para a enunciação do narrador uma imagem pictórica com que compõe o enunciado como se efetivamente fizesse as passagens entre pintura e discurso indicadas por Filóstrato de Lemnos quando se autonomeia "hermeneuta", em seus Eikones, comentando sua prática como "exercício de eloquência". Dessa maneira, o autor da ekphrasis inventa um narrador que amplifica um topos sobre o qual há concordância; por exemplo, o elogio do engenho, da perícia técnica de um pintor, do caráter extraordinário, da utilidade e da beleza da obra de arte. Depois de pequeno exórdio em que se apresenta, o narrador amplifica o topos, propondo descrever um quadro que atesta o engenho de um pintor."

${ }^{72}$ Lausberg (1972, p. 218-9); Lausberg (1991, II.224-35); Lausberg (1991, II.427).

${ }^{73}$ Webb (2009, p. 205-6).

${ }^{74}$ Webb (1999, p. 67).

${ }^{75}$ Phot., Homiliai 10.4
} 
en détail. Vale, entretanto, verificar que Bailly ao apresentar o sentido do adjetivo em questão

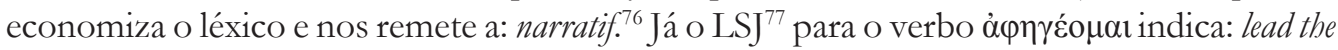
way from a point, and so generally, lead the way, go first, to be leader of, take up his command; em segunda acepção tem-se: tell, relate, assert. $\mathrm{O}$ adjetivo por sua vez segue o senso, apresentando-nos: narrative, $\lambda$ ó $\gamma$ s, simplesmente, tal como Bailly. Fato é que a ideia de comando e condução de um ponto de partida tanto fisicamente como animicamente é referendada pela lição de Nicolau que assertivamente revela a condição de completude que pode ser observada na narrativa em relação àquilo que é descrito.

A série latina dos praeexercitamina cujo representante aqui é Prisciano nos oferece o termo colligens. O verbo colligo, igere, $\sim$ egi $\sim$ ectum, cujo particípio presente é colligens, apresenta nada mais nada menos do que dezessete acepções segundo o OLD. Seus sentidos, deixando de lado alguns irrelevantes para nós: 1) to gather, collect, 2) barvest, 3) to pick up; 4) to collect, accumulate; 6) to bring together, 8) to collect (in a book), bring (literary works); 9) to bring together, esp. mentally, to collect, assemble (facts, instances, examples); 11) to deduce, infer, 12) to compute; 13) to bring together (into a single mass, process, action, etc.), concentrate, combine. ${ }^{78}$ Pelo que se pode e deve observar, a seleção lexical de Prisciano atende perfeitamente a demanda de sentido exigida

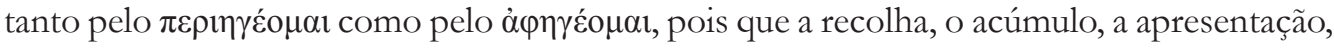
a reunião de elementos são sentidos atendidos pelo verbo e pela definição que proponho.

O termo que me parece pouco discutido, entretanto, é o particípio passivo antecedido

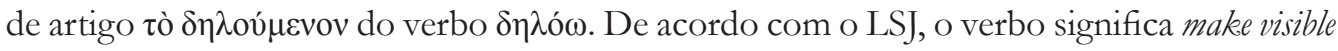
or manifest, show, exhibit, em segunda acepção, make known, disclose, reveal, prove, explain, set forth, indicate. Assim "aquilo que é mostrado" parece somenos, uma vez que semanticamente o verbo "mostrar" em português teve seu campo semântico físico estreitado em nome da abstração, da comprovação amiúde intelectual o demonstrar, quod demonstrat. É interessante pensarmos duas possibilidades, a meu ver, o sentido de revelar e o sentido de exibir, de sorte

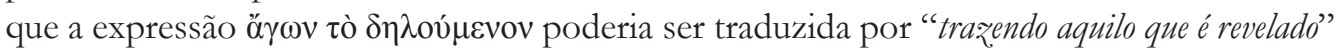
ou "trazendo o que é exibido", donde poder-se-ia ter, mesmo que contrariando a gramática grega que neste caso pontifica o uso adjetivo, "tražendo a revelação" ou "tražendo a exibição", tanto uma solução quanto outra, em seu matiz adjetivo ou em sua coloração substantiva, indicam a visualidade física do objeto, matizada pelos olhos da mente via écfrase. À essa

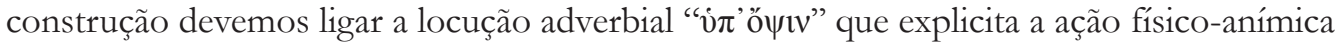
da visão mediada pelo procedimento ecfrástico.

Resta-nos assim discutir, a meu ver, um último elemento nestas definições, a saber,

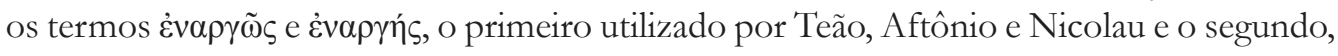

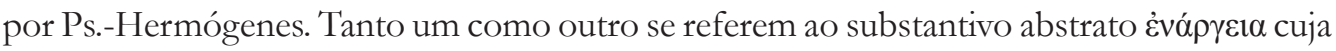
centralidade na écfrase em certa medida já se discutiu aqui, entretanto não suficientemente. A enargia - palavra já dicionarizada em português -, ou enárgeia - sua transliteração ao vernáculo -, está calcada em conceito retórico bem complexo. Partindo dos dicionários,

\footnotetext{
${ }^{76}$ Bailly (1984, p. 325).

${ }^{77}$ LSJ (1972, p. 288-9).

${ }^{78}$ OLD (2006, p. 351-2).
} 
observamos no LSJ: 1) clearness, distinctless, vividness, ou no Bailly: vue claire et distincte, clarté, évidence, ${ }^{79}$ cujo exemplo bem-vindo em ambos dicionaristas é Platão no Político. No trecho em questão o estrangeiro comentando seu próprio discurso sobre o rei, ao seu jovem interocutor, Sócrates, alerta o quão deficitário era seu próprio discurso dizendo:

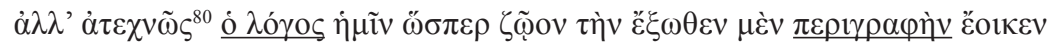

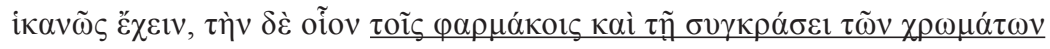

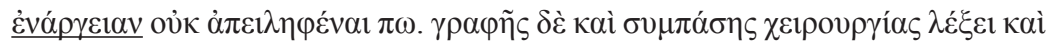

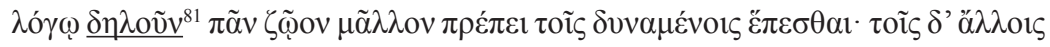

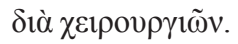

$[277 \mathrm{c}]$ mas nosso discurso apenas como uma pintura de um ser vivo parece ter um contorno externo suficiente, entretanto ainda não recebeu a

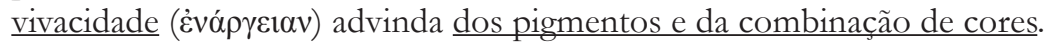
Mas, para quem é capaz de seguir um argumento, é mais adequado exibir (mostrar) todo e qualquer ser vivo pela palavra e pelo discurso do que pela pintura ou pela manufatura em geral; mas para outros é melhor fazê-lo por meio de obras de manufatura (artesanato). ${ }^{82}$

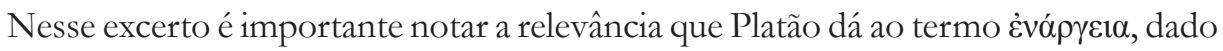
que esta virtude seria capaz de suprir as deficiências plásticas e cromáticas de um esboço,

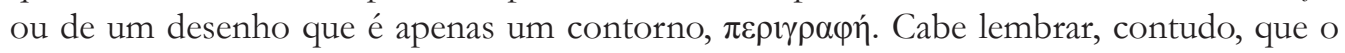

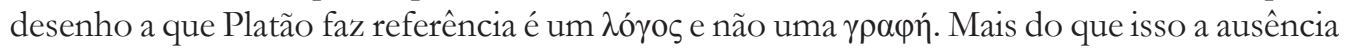
da qualidade "vivacidade" denota uma ausência de arte. A um só tempo Platão valoriza as palavras aplicando-lhes uma qualidade visual e acaba por desqualificar as artes visuais, isto é, apontar sua natureza sempre deficitária. Retomando as demais acepções dicionarizadas, LSJ ainda oferece: 2) clear and distinct perception; 3) rhet. vivid description em D. H., Lys. 7; II. clear view em Plb. 3.54 e, por fim, III. self-evidence: manifest facts. Ademais, o $\pi \varepsilon \rho \iota \gamma \rho \alpha \varphi \eta ́$ tornarse-ia não deficitário, logo $\gamma \rho \alpha \varphi \eta ́$, se houvesse a intervenção cromática da enargia. Assim, esta proporciona à imagem uma substância viva em tal medida que the retira o déficit que a caracteriza. O discurso, portanto, o $\lambda$ ó $\gamma_{0} \varsigma$ que para Platão poderia ser mais vigoroso que a pintura ganha, parece-me, mais força ainda se lhe concedermos uma qualidade que é comum à pintura como virtude a fim de lhe reduzir seu caráter deficitário, isto é, o $\lambda$ ófos torna-se

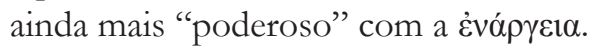

Além do substantivo, há mais dois níveis morfológicos, por assim dizer, de um mesmo campo semântico em jogo utilizados na definição de écfrase cuja importância lhe é essencial, já que corresponde a uma característica sine qua non, como vimos. Dos quatro

\footnotetext{
${ }^{79}$ Bailly (1984, p. 670). idibid: particul. t. de rhét. description animée, DH., Lys. 7.

${ }^{80} \dot{\alpha} \tau \varepsilon \chi \nu \tilde{\omega} \zeta$ ainda que possa significar ausência de técnica, o que semanticamente seria uma ótima opção nesse contexto, neste caso especificamente é utilizado na estrutura comparativa em correlação com

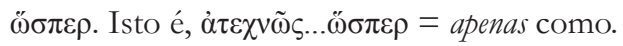

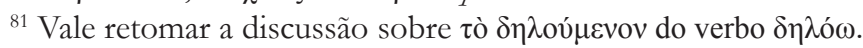

${ }^{82} \mathrm{Pl} .$, Plt. 277c.
} 


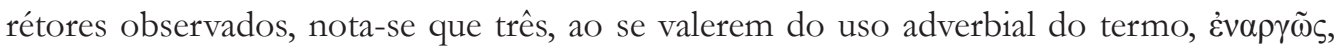
vividamente, ${ }^{83}$ ou o aplicam sobre o adjetivo $\pi \varepsilon \rho ı \gamma \eta \mu \alpha \tau \iota \kappa o ́ s$, ou sobre o particípio presente assomado à locução adverbial vं $\pi^{\prime}$ ö $\psi v v$ ö $\gamma \omega v$, isto é, sobre o efeito resultante do discurso

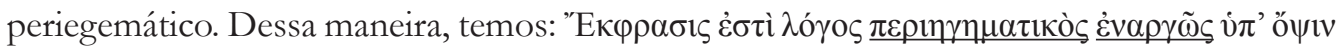
ö $\gamma \omega v \underline{\varepsilon} v \alpha \rho \gamma \tilde{\omega} \zeta$. Assim em vernáculo temos: "Écfrase é o discurso vividamente periegemático que conduz..." ou "Écfrase é o discurso periegemático que conduz vividamente diante dos

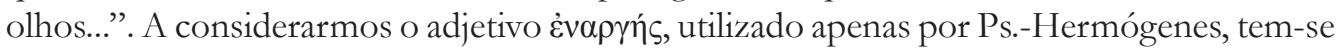

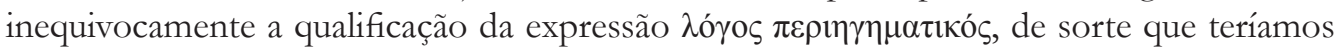

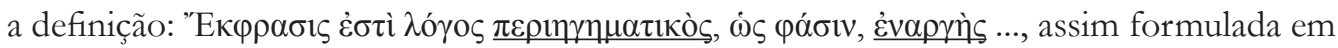
português: "Écfrase é o discurso periegemático, como dizem, vívido que..."; a ser levada em consideração as acepções propostas pelo LSJ teríamos: "Écfrase é o discurso periegemático, como dizem, palpável on visivel que...". ${ }^{84}$

Resumidamente, posso oferecer as seguintes traduções para as definições:

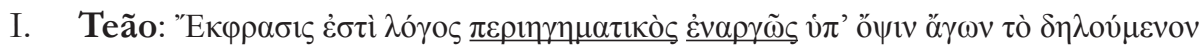
Écfrase é um discurso vividamente percursivo ${ }^{85}$ [ou periegemático] que traz. o que é revelado diante dos olhos.

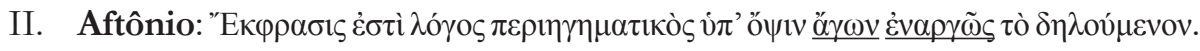
Écfrase é um discurso percurssivo [ou periegemático] que traz vividamente o que é revelado diante dos olhos.

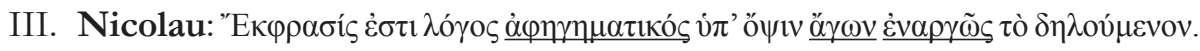
Écfrase é o discurso condutivo [dirigido on afegemático] que traz vividamente o que é exibido diante dos olhos.

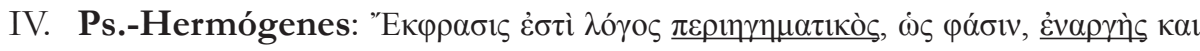

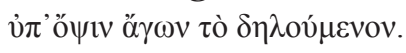

Écfrase é um discurso percursivo [ou periegemático], como dizem, palpável [ou visivel] que traz o que é revelado diante dos olbos.

Essas primeiras considerações filológicas levam-nos a pontos importantes sobre a écfrase. O primeiro é a explicitação de um comando ecfrástico, isto é, o enunciador se propõe textualmente como alguém que irá dirigir o enunciatário pelos bosques da fição, ou melhor, pelos caminhos e descaminhos da narrativa. Sua posição de superioridade advém de sua condição de hermeneuta, de exegeta. Converte-se o enunciador ecfrástico nos olhos do enunciatário. Soma o narrador em si mesmo os olhos que lhe são próprios, os do "eu" e os que the são

\footnotetext{
83 contra LSJ (1972, p. 556): visibly ou manifestly.

${ }^{84}$ LSJ (1972, p. 526). Ainda como possibilidade LSJ oferece para o sentido adjetivo: "proeminente ou manifesto aos olhos da mente".

${ }^{85}$ No minicurso realizado na UFRJ, Tatiana O. Ribeiro sugeriu o termo "percursivo", ainda que um neologismo, parece-me autorizado já que percursão pode se referir ao percurso.
} 
alheios, os do "tu" discursivo. A sobreposição desses dois níveis é capaz de gerar a visão

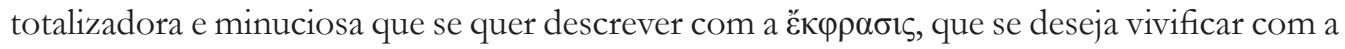

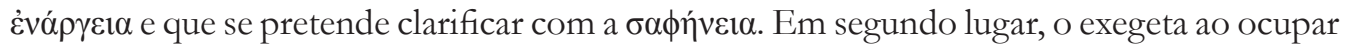

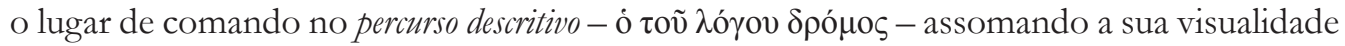
com a visualidade de seu "exército", de seus seguidores faz seu discurso ganhar validação argumentativa, já que de saída coopta o enunciatário a ver com seus olhos.

Nesse sentido, tomemos a autoridade de Filóstrato, o velho, no proêmio de suas Imagines:

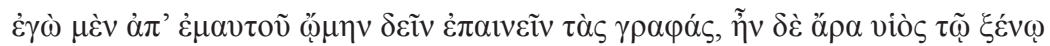

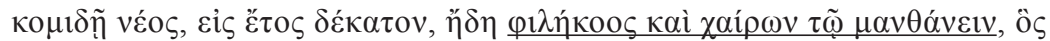

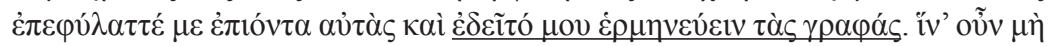

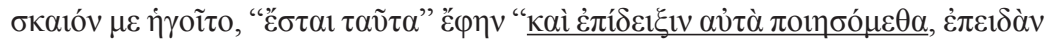

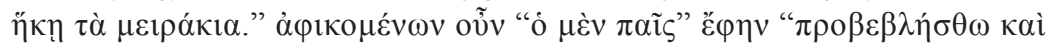

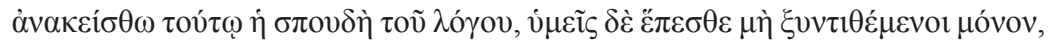

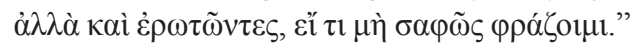

Eu mesmo pensava que deveria fazer um elogio às pinturas e, justamente, lá se encontrava o jovem filho de meu anfitrião, de dez anos, jáávido ouvinte e alegre em aprender, que sem tirar os olhos de mim, enquanto observava, implorava-me que as explicasse. Para que não me considerasse rude, disse eu: Assim será. E faremos isso na forma de discursos, depois que os jovens chegarem". "O menino", disse eu, "que seja posto à frente, e que meu esforço ao discursar seja dedicado a ele; quanto a vocês, acompanhem-se e não concordem apenas, mas façam perguntas caso não me faça claro." ${ }^{\circledR 6}$

O interlocutor preferencial de Filóstrato - há outros -, no caso um menino de 10 anos de idade é "ávido ouvinte e alegre em aprender" e implora ao sofista que explique

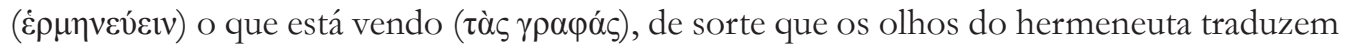
aos olhos do menino as pinturas a partir do discurso que é ouvido. Ruth Webb, pautandose em Barthes, ${ }^{87}$ afirma que claramente uma descrição verbal nunca pode substituir completamente o seu objeto, afinal a "composition of any description involves the selection of the

\footnotetext{
${ }^{86}$ Philostr. Im., proem. 5.1-11. Todas as traduções de Filóstrato deste trabalho são de Rosângela S. S. Amato. ${ }^{87}$ Barthes (1968, p. 87): “si elle n'était pas soumise à un choix esthétique ou rhétorique, toute "vue" serait inépuisable par le discours: il y aurait toujours un coin, un détail, une inflexion d'espace ou de couleur à rapporter; et d'autre part, en posant le référent pour réel, en feignant de le suivre d'une façon esclave, la description réaliste évite de se laisser entraîner dans une activité fantasmatique (précaution que l'on croyait nécessaire à l'“objectivité" de la relation); la rhétorique classique avait en quelque sorte institutionnalisé le fantasme sous le nom d'une figure particulière, l'hypotypose, chargée de "mettre les choses sous les yeux de l'auditeur", non point d'une façon neutre, constative, mais en laissant à la représentation tout l'éclat du désir (cela faisait partie du discours vivement éclairé, aux cernes colorés: l'illustris oratio); en renonçant déclarativement aux contraintes du code rhétorique, le réalisme doit chercher une nouvelle raison de décrire".
} 
details to be included". ${ }^{88}$ Tais detalhes e a impossibilidade de tradução da imagem pelo discurso, parece-me, esbarram na condução, na liderança do enunciador, que pode ser traduzida por esta "selection of details". A escolha do que irá se descrever é o próprio exercício do poder do hermeneuta sobre o enunciatário, conduzindo seu olhar. Tratando de uma aproximação literária da écfrase, Webb completa que esta contribui para "the rhetorical strategies favored by authors in presenting their subject." 89

A scholar ainda reflete que o objetivo da écfrase se ocupa menos de dar um relato completo e preciso de um objeto particular do que transmitir o efeito da percepção do objeto incidente sobre o espectador, o leitor. Nesse sentido, primeiramente, o enunciador apela para a imaginação do enunciatário, muita vez, por intermédio do uso de imagens generalizadas e generalizantes que provavelmente correspondem a uma experiência prévia da audiência, ou

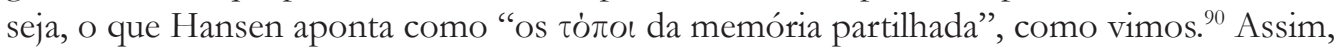
o discurso vívido evoca a percepção do efeito sobre o ouvinte, fazendo-lhe sentir "como se" na presença da cena. ${ }^{91}$

\section{Dizer SEM NOMEAR}

Mesmo que a Retórica a Herênio, Cícero e Quintiliano não nos ofereçam uma doutrina explícita sobre a écfrase, há que ser considerados conceitos fronteiriços observados por estas autoridades. Froma Zeitlin em recente trabalho apresenta uma pequena síntese sobre esta questão dizendo que, embora o conceito de écfrase não tenha sido nomeado explicitamente, ou ainda, claramente cunhado na cultura romana do fim da República sem que haja também quaisquer referências helenísticas, isto não significa que aqueles romanos e estes gregos não a tenham "broadly understood in the same terms." 92 Cícero, o autor da Retórica a Herênio e mais tarde Quintiliano entre outros endereçaram suas discussões para as virtudes do discurso vívido, daí ser fundamental o conceito de evidentia que traduz, de acordo com Quintiliano, o conceito grego de $\varphi \alpha v \tau \alpha \sigma i ́ \alpha .{ }^{93}$ Dubel, por seu turno, aponta com precisão que mesmo que haja certa uniformidade no conceito de écfrase desde Teão até Prisciano, já no que diz respeito a conceitos como enargia, fantasia e evidência não há muita uniformidade, portanto o campo é pantanoso e depende de várias fontes distintas. Diz a pesquisadora:

force est de constater qu'un grand nombre de termes gravitent dans le champ de l'évidence, sans qu'il semble possible d'établir de claires distinctions. L'oeuvre de Quintilien témoigne bien de cette confusion: non seulement le rhéteur traite de l'enargeia de manière

\footnotetext{
${ }^{88}$ Webb (1999, p. 59-60).

${ }^{89}$ Webb (1999, p. 62).

${ }^{90}$ Hansen (2006, p. 86).

${ }^{91}$ Webb (1999, p. 64).

92 Zeitlin (2013, p. 18).

${ }^{93}$ Quint., Inst. 8.3.61-4.
} 
éclatée, en fonction de points de vue différents, mais il dénonce les multiples subtilités auxquelles se complaisent les traités. ${ }^{94}$

Quintiliano, por exemplo, não trata formalmente da descrição, antes usa os termos descriptio, hipotipose, diatipose inadvertidamente sem os definir. Já ao tratar da enargia, dirá que Cícero a toma como euidentia ou illustratio (6.2.32), ou que outros rétores a chamaram de repraesentatio (8.3.32), ou que de acordo com Celso a enargia define-se pela expressão sub oculos subiecto (9.2.40), como a seguir verificaremos. Sandrine Dubel esclarece precisamente que tamanha abundância e variedade terminológica torna muito complexa, senão impossível, uma classificação. Fica evidente, diz a scholar, que à época de Quintiliano, lidamos com uma terminologia flottante e mal fixée, ainda assim resume que o termo pode significar: a) a qualidade de uma prova, entendida como sua própria capacidade de estar sob os olhos; b) a expressão do poder figurativo da linguagem; c) o processo que visa produzir ou um tropo, ou uma figura; d) o efeito resultante do discurso, isto é, uma imagem mental despertada pelo texto. ${ }^{95}$

Melina Rodolpho, por seu turno, seguida por mim mesmo, ainda que por mim tenha sido orientada - aqui não proponho um bom paradoxo, mas tão somente uma possível comprovação da máxima homines, dum docent, discunt - faz um vastíssimo percurso por estes conceitos, a saber, a fantasia, a enargia/ evidência e a hipotipose. ${ }^{96} \mathrm{Em} 2013$, também dediquei parte de meu trabalho a esta questão, ${ }^{97}$ tentando proceder uma síntese que pudesse ser confirmada até então, tendo vista os trabalhos mais recentes sobre o tema. ${ }^{98}$

A pesquisadora esclarece inicialmente a inequívoca relação - implícita - entre a $\varphi \alpha v \tau \alpha \sigma i ́ \alpha$ e a écfrase, digo implícita já que esta não apresenta aquela como um dado correlato, conforme ou afim. Entretanto, não há como dissociar os conceitos, afinal a écfrase é o mecanismo/procedimento retórico "que traz vividamente diante dos olhos aquilo que é

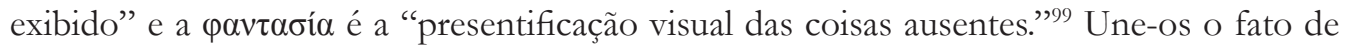
tratarem da visualização daquilo/e que está ausente. Conquanto a diversidade de usos da

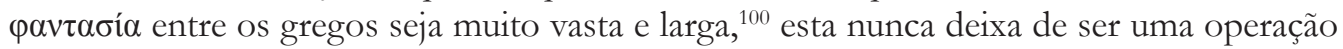
apenas intelectual, portanto desnecessário afirmar que é independente da operação discursiva, do $\lambda o ́ \gamma o s$, pois que é uma operação exclusiva do pensamento - é imaginatio. Já a écfrase, em caminho diverso, pode até mesmo possuir um motivador prévio ao ato da enunciação, uma operação intelectual de visualização, uma $\varphi \alpha v \tau \alpha \sigma i ́ \alpha$, mas antes de tudo deve ser, alfim e ao cabo, um $\lambda o ́ \gamma o s$, uma oratio. Esta ideia, isto é, a utilização da $\varphi \alpha v \tau \alpha \sigma i ́ \alpha$ no âmbito da produção discursiva é operada pelo autor do Tratado sobre o Sublime, ao afirmar que alguns a

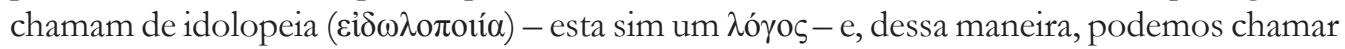

\footnotetext{
${ }^{94}$ Dubel (1997, p. 250-1).

${ }^{95}$ Dubel (1997, p. 251-2).

${ }^{96}$ Rodolpho (2012, p. 87-137): fantasia: enargia/evidência (p. 143-56), hipotipose (p. 158-63).

${ }^{97}$ Martins (2012, p. 13-23).

${ }^{98}$ Martins (2013, p. 22-25).

${ }^{99}$ Rodolpho (2012, p. 196).

${ }^{100}$ Pl., Tht. 195d; Arist., de An. III. 427b-429a; Plot. 4.4.12; S.E., M. 7.236; Cic., Acad. post. 1.11.40-2. Peters (1977, p. 187).
} 
indistintamente de $\varphi \alpha v \tau \alpha \sigma i ́ \alpha$ todo e qualquer pensamento capaz de produzir um discurso. Daí

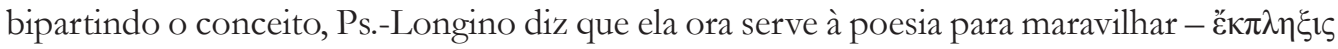

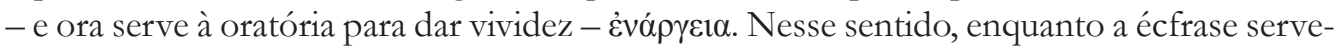
se obrigatoriamente da enargia, a enargia é produzida pela $\varphi \alpha v \tau \alpha \sigma i ́ \alpha$.

Um outro conceito que se associa à écfrase, entretanto é operado por algumas

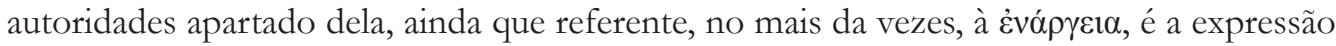

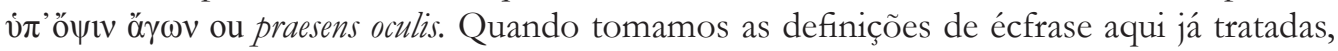
observa-se que em todas há uma referência aos olhos. Naturalmente seu uso no caso é conotativo, visto que a exposição aos olhos é discursiva e não física, nesse sentido o $\lambda$ ó tal ponto é virtuosamente elaborado que o objeto por ele "desenhado" surge, trazendo ou

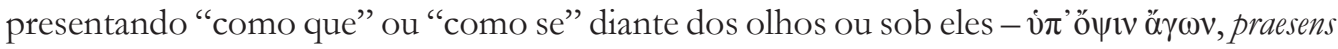

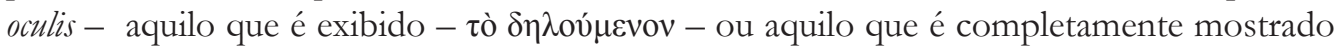
- quod demonstrat ${ }^{101}$-, assim dos olhos apenas posso afirmar, como já o fizera o autor incerto dos Schemata dianoeas quae ad rhetores pertinent, ${ }^{102}$ que são incorpóreos. Quintiliano falando de Cícero ${ }^{103}$ diz que a ideia de o discurso "pôr diante dos olhos" - sub oculos subiectio - costuma ocorrer não numa indicação de evento, mas quando o evento é detalhadamente exibido, tais detalhes - uma interferência fundamental do enunciador, como vimos - parecem estar

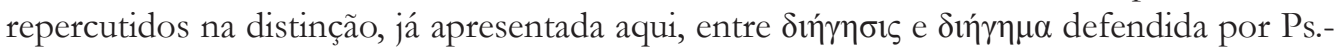
Hermógenes. Dessa maneira, conquanto este rétor ou aqueles não estejam tratando de écfrase especificamente, ou não tenham manifestado abertamente uma relação com a écfrase, os olhos incorpóreos nesses casos tratam da explicitação pormenorizada de detalhes (da qual fala Lausberg), mais do que isto põem em «evidência» - com o perdão do trocadilho - a importância da Ẻvó $\rho \gamma \varepsilon ı \alpha$ como elemento, de um lado persuasivo; de outro lado, ornamental a serviço do discurso elaborado. Plínio, o Jovem, por seu turno, sinaliza para a importância desses olhos em sua descriptio que se efetiva como topografia de sua vila em Tusco. Vejamos:

\begin{abstract}
Similiter nos ut "parua magnis", ${ }^{104}$ cum totam uillam oculis tuis subicere conamur, si nihil inductum et quasi deuium loquimur, non epistula quae describit sed uilla quae describitur magna est. Verum illuc unde coepi, ne secundum legem meam iure reprendar, si longior fuero in hoc in quod excessi. ${ }^{105}$
\end{abstract}

De modo semelhante, "para comparar pequenas às grandes coisas", quando tento pôr a vila inteira diante de teus olhos, se nada estranho

\footnotetext{
${ }^{101}$ Vale pensar aqui no prefixo de em demonstrat, como indicador de ação completa, detalhada.

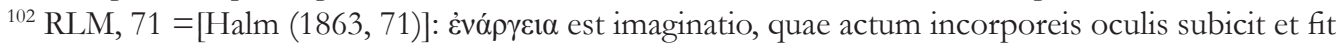
modis tribus: persona, loco, tempore.

${ }^{103}$ Quint., Inst. 9.2.40 e Cic., De Or. 3.202.

${ }^{104}$ Nota de João Angelo Oliva Neto: para comparar pequenas às grandes coisas: parua magnis. Alusão a verso de Virgílio, Geórgicas (4, 176): si parua licet componere magnis, "se é lícito comparar pequenas coisas às grandes".

${ }^{105}$ Oliva Neto (2015, p. 187).
} 
e impertinente falei, não é a epístola que descreve que é longa, mas sim a vila que é descrita. Porém, se me dilatei nesta digressão, para que eu não seja repreendido com justiça segundo minha própria lei, volto ao ponto em que comecei. ${ }^{106}$

Goldhill, ${ }^{107}$ discutindo as "formas de atenção" da recepção que são explicitadas nas écfrases, principalmente se compararmos os epigramas ecfrásticos e as écfrases interventivas épicas, aponta justamente para este trecho indicando que uma das formas de atenção que podemos ter é justamente o tamanho das écfrases. O próprio Plínio diz que, se seu leitor ficar cansado de ler a carta, ele pode parar e recomeçar em outro momento, da mesma maneira que se estivesse andando por sua vila, ele poderia parar, descansar e recomeçar em outro momento. ${ }^{108}$ Parece-me que Plínio adapta o preceito de que a écfrase é obrigatoriamente adequada ao seu objeto, isto é, se é o objeto acerbo, acerba será a écfrase, se suave é o objeto, assim será sua descrição, se seu objeto é grandioso, assim será sua representação em texto. Como bem lembra Hansen, o limite dessa imposição prescritiva é sua própria inviabilização e dá como exemplo um texto de Borges:

...En aquel Imperio, el Arte de la Cartografía logró tal Perfección que el mapa de una sola Provincia ocupaba toda una Ciudad, y el mapa del Imperio, toda una Provincia. Con el tiempo, estos Mapas Desmesurados no satisficieron y los colegios de Cartógrafos levantaron un Mapa del Imperio, que tenía el tamaño del Imperio y coincidía puntualmente con él. Menos adictas al Estudio de la Cartografía, las Generaciones Siguientes entendieron que ese dilatado Mapa era Inútil y no sin Impiedad lo entregaron a las Inclemencias del Sol y de los Inviernos. En los Desiertos del Oeste perduran despedazadas Ruinas del Mapa, habitadas por Animales y por Mendigos; en todo el País no hay otra reliquia de las Disciplinas Geográficas.

Suárez Miranda, Viajes de varones prudentes Libro cuarto, cap. XLV, Lérida, 1658. ${ }^{109}$

Chinn, por seu turno, crê que Plínio construiu sua descrição produzindo um "efeito de realidade" por meio do qual a propagação dos detalhes na narrativa serve para criar a ilusão de que os referentes discursivos estão realmente presentes para o leitor/enunciatário. ${ }^{110} \mathrm{Na}$ verdade, como vimos, mesmo que todos os elementos fossem efetivamente traduzidos para a linguagem verbal, ainda assim a impossibilidade desse tipo de descrição confirmar-se-ia. Logo a seletividade dos detalhes, e no caso desta carta de Plínio, está sempre a serviço do

\footnotetext{
${ }^{106}$ Oliva Neto (2015, p. 193).

${ }^{107}$ Goldhill (2012, p. 99-101).

${ }^{108}$ Plin., Ep. 5.6.41.

${ }^{109}$ Borges (1946, p. 53).

${ }^{110}$ Chinn (2007, p. 270-1).
} 
condutor da écfrase, de sorte que se há um efeito de realidade este está sendo determinado por uma necessidade imposta pelo descritor a fim de amplificar sua propriedade. Ao propor uma epístola tão grande quanto sua propriedade Plínio faz uso da concepção de periegese ou de discurso periegemático que, de um lado, apresenta elementos referenciais do objeto descrito - a vila - e, de outro lado, constrói a metáfora da própria escritura. Assim o enunciatário de Plínio está sob seu comando duas vezes, ao mostrar quão bela e grande é sua vila e quão é capaz de produzir uma écfrase virtuosa, por ser clara e vívida.

\section{Construção DE EFEITOS}

\section{OLHOS QUE FAZEM VER}

Considerando-se assim a importância dos olhos incorpóreos na constituição da écfrase, paratática ou hipotática, interventiva ou autônoma, doutrinária ou pragmática, nomeada ou não, atribui-se, pois, relevo fundamental às luzes e às sombras; ao cromatismo ou à sua ausência. Entretanto, há que se observar que concorrem dois olhares possíveis na écfrase: aquele em que, pode-se dizer, o enunciador conduzindo a descrição apresenta sua visão e aquele em que é atribuído ao enunciado, os objetos presentados visualmente. Explico. Uma possibilidade

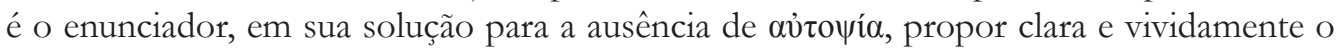
que não viu. Outra é a visão atribuída aos agentes da narrativa ecfrástica no enunciado, de sorte que as personagens visualizam em conformidade às necessidades do enunciado e daí o enunciador apenas agencia o olhar da personagem. Assim, um excelente exemplo de olhar em que o enunciador apenas agencia a visão da personagem é quando Odisseu se vê diante do palácio de Alcino e é assolado por uma luminosidade "ecfrástica":

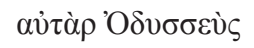

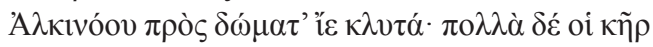

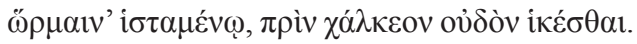

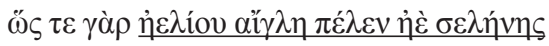

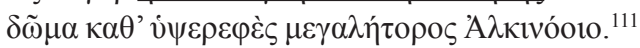

\section{Mas Ulisses}

aproximou-se do palácio glorioso de Alcino. Aí, de pé, muito se lhe revolveu o coração, antes de transpor o limiar de bronze:

pois reluzia o brilho do sol e reluzia o brilho da lua no alto palácio do magnânimo Alcino.

É curioso nessa passagem o uso do substantivo aî́r $\lambda \eta$ como objeto do verbo $\pi \dot{\varepsilon} \lambda \omega$ em $\pi \varepsilon ́ \lambda \varepsilon v$, pelo que, com a presença do herói diante do palácio, a luminosidade tornavase brilhante, luzidia, reluzente, e essa era tanto do sol como da lua, concomitantemente. Esta passagem dá início à écfrase, daí também pode ser lida em chave metalinguística já

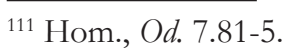




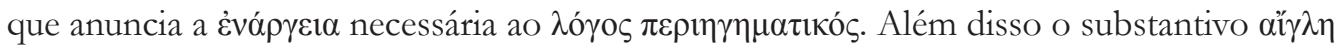
ultrapassa o simples brilho, afinal pode se referir à radiância do próprio Olimpo, ${ }^{112}$ o que dá à passagem estatuto divino, ou se referir também ao dia do nascimento em que se ganha a luz, ${ }^{113}$ o que proporciona base argumentativa na alteração do destino de Odisseu que a

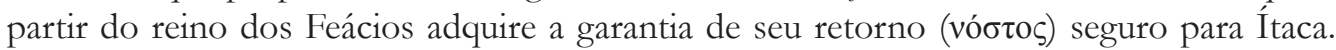
Mas a luminosidade, principalmente, como indica o LSJ, pode advir do brilho of dream light in sleep, ${ }^{114}$ o que confere à cena estatuto onírico, um fantasma. ${ }^{115}$

Já em Lívio na passagem sobre a batalha do lago Trasímeno, o olhar ou a impossibilidade de ver das personagens justifica, em certa medida, derrota avassaladora de Roma frente às forças de Aníbal. Essa é apresentada pelo enunciador de sorte que as personagens tornam-se meros instrumentos de sua argumentação, portanto sua falta de visão, das personagens, não se justifica por um discurso atribuído aos próprios romanos, conferindo credibilidade argumentativa, fides:

magnae partis fuga inde primum coepit; et iam nec lacus nec montes pauori obstabant; per omnia arta praeruptaque uelut caeci euadunt, armaque et uiri super alium alii praecipitantur. ${ }^{116}$

A maior parte começa a fuga; e já, nem o lago, nem os montes deram fim ao desespero. Tanto por todos os desfiladeiros como pelos precipícios como se fossem cegos evadiam-se, tanto as armas como os homens uns sobre os outros se precipitavam. ${ }^{117}$

A expressão uelut caeci enadunt de Lívio assim como a ação desordenada de fuga apresentada no trecho baliza-se mais precisamente tendo em vista a leitura de Políbio que diz:

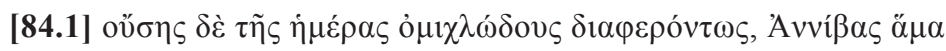

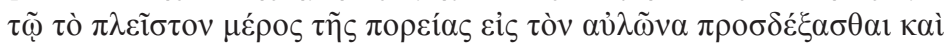

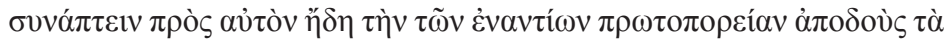

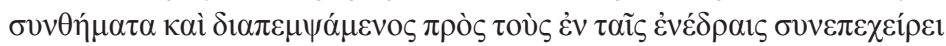

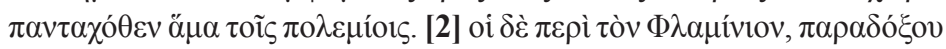

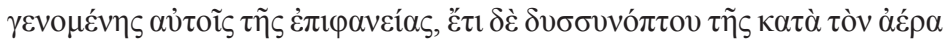

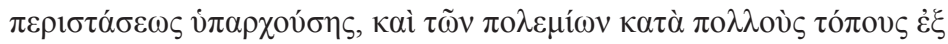

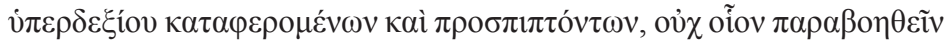

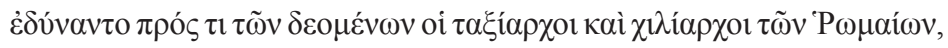

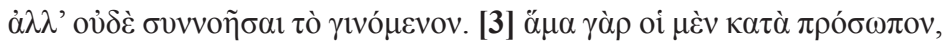

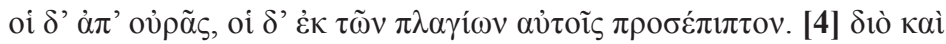

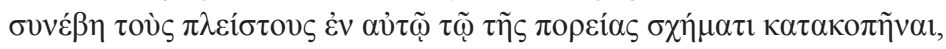

\footnotetext{
${ }^{112}$ S., Ant. 610.

${ }_{113}$ Pi., N. 1.35.

${ }^{114}$ S., Ph. 831.

${ }^{115}$ LSJ (1977, p. 35).

${ }^{116}$ Liv. 22.5.5-6.

117 Tradução nossa.
} 


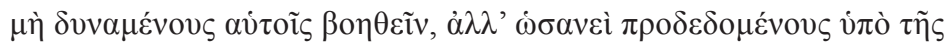

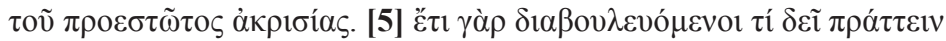

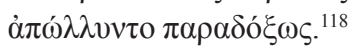

[84.1] Como o dia estivesse singularmente nublado, enquanto a maior parte da expedição aguardava no vale e a vanguarda dos oponentes já se aproximava dos seus, Aníbal seu o sinal, despachou aos emboscados e caiu de todos os lados por sobre os inimigos. [2] Os homens de Flamínio, ante a surpresa da aparição e a dificuldade de enxergar, dada a condição do ar, e porque os inimigos desciam e atacavam de muitos locais em posição superior, não apenas não conseguiam os centuriões e os tribunos romanos socorrê-los adequadamente, como sequer compreender o que se passava. [3] Uns atacavam de frente, outros, pela retaguarda, outros, ainda, pelos flancos, todos ao mesmo tempo. [4] Em razão disto muitos foram massacrados em sua própria formação, impossibilitados de socorrerse mutuamente, como se houvessem sido traídos pela falta de juízo de seu comandante. [5] Mesmo quando deliberavam sobre o que era necessário fazer, pereciam surpreendentemente. ${ }^{119}$

Afora a questão do olhar e da visibilidade ecfrástica, é lugar-comum desse tipo de mecanismo discursivo a exploração das cores como forma de efeito de realidade que é capaz de fazer com que os olhos do enunciador substituam os do enunciatário. Homero, Virgílio e Filóstrato, parece-me, registraram de forma cabal o enunciado de cores em suas écfrases. Vejamos.

\section{BRILHOS E CORES}

É inegável que outro elemento da visibilidade ecfrástica é o uso sistemático das

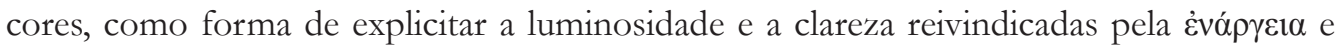
pela $\sigma \alpha \varphi \eta ́ v \varepsilon ı \alpha$, características essenciais do procedimento poético-retórico aqui observado. Parece-me que em virtude de a primeira manufatura constituída verbalmente ter sido obra de Hefesto, a recuperação da matéria-prima por ele operada sejam justamente os metais preciosos: ouro, prata e bronze e, nesse sentido, a ele associados como lugar-comum, tomese a Ilíada:

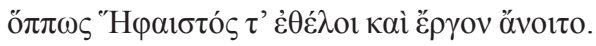

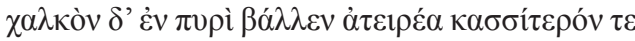

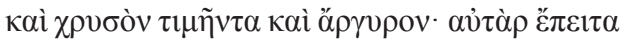

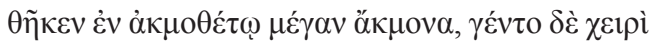

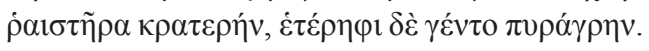

\footnotetext{
118 Pol. 3.84.1-5.

119 Tradução de Breno Battistin Sebastiani.
} 
consoante Hefesto queria e o trabalho o exigia.

Lançou para o fogo bronze renitente e estanho e ouro precioso e prata. Logo em seguida colocou sobre o suporte uma grande bigorna; com uma das mãos pegou num martelo ingente; com a outra, nas tenazes. ${ }^{120}$

Essa referência parece animar a série histórica até pelo menos Paulo Silenciário, no mundo cristão de Bizâncio. Já na Odisseia, na descrição do Palácio de Alcino tem-se:

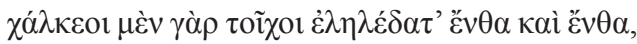

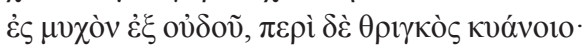

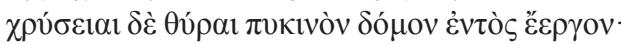

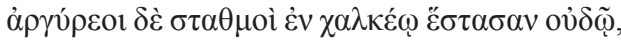

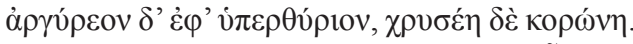

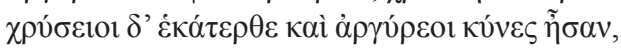
oûऽ "H

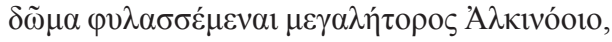

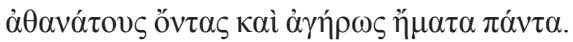

De bronze eram as paredes que se estendiam daqui para ali, até o lugar mais afastado da soleira; e a cornija era da cor azul. De ouro eram as portas que se fechavam na casa robusta, e na brônzea soleira viam-se colunas de prata.

Prateada era a ombreira e de ouro era a maçaneta da porta.

De cada lado estavam cães feitos de ouro e de prata, que fabricara Hefesto com excepcional perícia para guardarem o palácio do magnânimo Alcino: eram imortais e todos os seus dias eram isentos de velhice. ${ }^{121}$

\section{AMPLIACÁAO DOS SENTIDOS}

Embora retoricamente a sinestesia não tenha sido nominada como figura de retórica pelo antigos, apesar de sua etimologia nos convidar para este universo, curiosamente Quintiliano a aplica ao tratar dos tipos de vozes dos oradores, sintetizando, entre outros, Cícero. Diz o rétor: Nam est et candida et fusca, et plena et exilis, et lenis et aspera, et contracta et fusa, et dura et flexibilis, et clara et optusa. Spiritus etiam longior breniorque. ${ }^{122} \mathrm{O}$ que se verifica no excerto é justamente uma sistemática aplicação de sinestesias para clarificar as qualidades vocais. Tomemos aqui a primeira categoria, isto é, a nox candida ${ }^{123}$ cujo oposto é a nox

\footnotetext{
${ }^{120}$ Hom., Il. 18.473-7.

${ }^{121}$ Hom., Od. 7.86-94.

${ }^{122}$ Quint., Inst. 11.3.15.

${ }^{123}$ OLD (2006, p. 265), em última acepção, 10ª (of vocal tone) Bright, clear. LS (1987, p. 277): II. Trop., pure, clear, serene, clean, spotless, etc. A. Of the voice, distinct, clear, pure, silver-toned (opp. fuscus), Quint., Inst.
} 
fusca. ${ }^{124} \mathrm{O}$ rétor nesse caso registra que a qualidade essencial da voz, que deveria ser auditiva, é representada por qualidades visuais, afinal tanto a voz pode ser alva, clara, branca como pode ser opaca, escura, negra. Neste artigo não tenho a preocupação de traduzir o sentido indicado pelo rétor aos tipos de vozes, entretanto me parece óbvio que para qualificá-las vale-se desta figura. Há quem defenda - e isto me é caro - que Quintiliano opera simplesmente uma metáfora e, dessa forma, entendo a sinestesia como uma translatio sensus ou uma metáfora de percep̧cão, com a vênia do neologismo.

É verificável o quão essencial é o lugar da visão na definição da écfrase. Conquanto a écfrase seja um mecanismo ou processo de visualização que torna evidentes por vivacidade e clareza objetos descritos, é forçoso dizer que a visualidade construída extrapola o sentido que lhe é inerente, isto é, a visão. Esta vaza para outros sentidos de modo que a "visualidade" passa a ser dividida por outros sentidos em um dos polos da translatio, da metáfora. Isto, a que modernamente deu-se o nome de sinestesia - há uma origem neurológica -, a meu ver, é, portanto, uma metáfora especializada. ${ }^{125}$ Assim quando Dante na Comédia diz que "pouco a pouco me lançava aonde sol é silente - a poco a poco mi ripigneva là dovel sol tace", ${ }^{126}$ transmite a ideia de que o sol possui um predicado essencial que não é seu brilho ou calor; isto faz vazar sua característica inerente essencial do sentido da visão para o da audição, ampliando as camadas de sentido do referente, Dante tornou o "astro rei” mais vivo, ao torná-lo além de brilhante e quente, silente. Assim à sua claridade e brilho naturais, pode-se unir seu poder de silêncio o que acabou por amplificar a visão que se tem sobre ele, tornando-o, por assim dizer, mais presente, mesmo que o poeta no caso esteja tratando justamente do lugar em que não há sua presença - o inferno. Barbetti ao tratar de écfrases medievais, mais especificamente de um trecho do Purgatório de Dante informa que a écfrase emprega mais do que o sentido da visão; a audição e o olfato, muita vez, têm importância na construção de experiências e traduções na composição poética. ${ }^{127}$

Partindo dos textos ecfrásticos mais antigos, estes já nos revelam a valorização desta metáfora de percepção, a sinestesia. Homero, ao falar das mulheres feácias dirigindo suas rocas e

11.3.15; Plin., Nat. 28.6.16, \58.

${ }^{124}$ OLD (2006, p. 751), na terceira acepção propõe: (of the voice) husky, hoarse, cf. Suet., Nero 20.1. Já o LS (1987, p. 798) mais abundante: Transf., of the voice, indistinct, husky, hoarse (opp. candidus): et vocis genera permulta: candidum (al. canorum) fuscum, leve asperum, grave acutum, etc., Cic., N.D. 2.58.146 Mos. and Orell. N. cr.; cf.: est (vox) et candida et fusca et plena et exilis, etc., Quint., Inst. 11.3.15; Plin., Nat. 28.6. 16, \58: hic etiam fusca illa vox, qualem, etc., Quint. 11.3.171 (for which Cic., Brut. 38.141, subrauca).

${ }^{125}$ Bradley (2013, p. 127-8): "As we know, synaesthesia is a complicated neurological condition in which stimulation of one sensory pathway leads to automatic, involuntary experiences in a second sensory pathway. In these terms, the ancients not were not synaesthetic any more than they were colour-blind. However, this does not mean that we should not think about how and why associations between the different senses were taking place in ancient thought, or indeed revisit (...)"

${ }^{126}$ Dante, Inf. 1.59-60.

${ }^{127}$ Barbetti (2011, p. 30). 


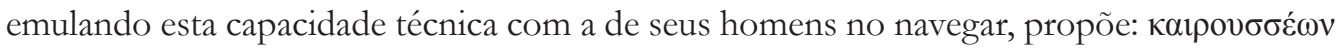

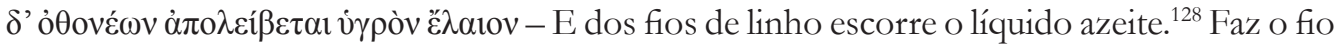
do tecido produzir textura tão suave e lisa que chega a escorrer da própria roca. Mais adiante,

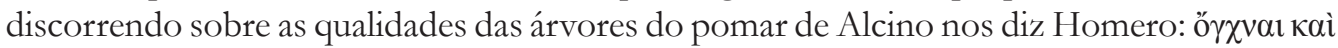

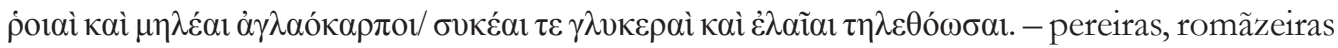
e macieiras de frutos brilhantes;/ figueiras que davam figos doces e viçosas oliveiras. ${ }^{129}$ Conquanto o brilho de peras, romãs e maçãs seja referencialmente razoável, pensarmos que os figos sejam doces visualmente marca precisamente uma operação sinestésica, já que a doçura não é denotativamente qualidade visual.

A audição tem um lugar importante na construção ecfrástica na épica homérica, como se a visualidade pudesse em certa medida fornecer elementos de sua própria transmissão poética, no caso oral. Explico. Ao tomarmos a oralidade como cerne da poesia homérica, obviamente a visualidade lá operada ocupa-se também e insistentemente do sentido da audição, já que sem ela o que ter-se-ia é sua negação, a escrita. $\mathrm{Na}$ Ilíada, em meio à écfrase do escudo, quando das bodas - negação do próprio $\mu \tilde{v} \theta$ os, dado que a infidelidade faz parte

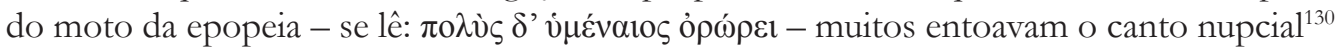

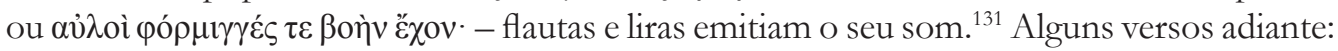

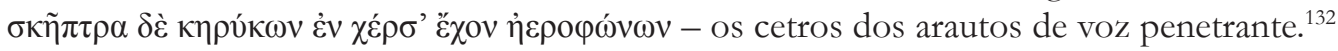

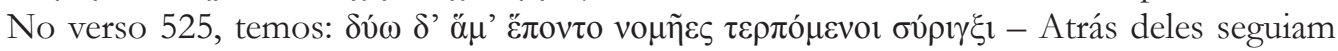
dois pastores, deleitando-se ao som da flauta. O que se nota, pois, é a figuração poéticovisual de momentos musicais e oratórios, isto é, a transposição da música e do som (mais genericamente) para o elemento cinzelado - o escudo - valendo-se da composição poética.

Em Hesíodo o mesmo procedimento é utilizado no Escudo de Héracles:

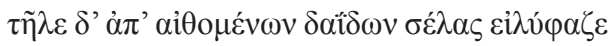

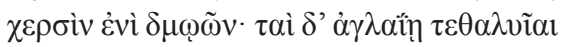

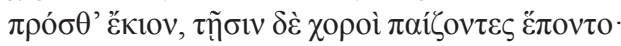

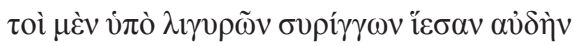

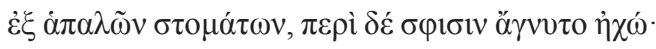

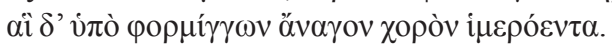

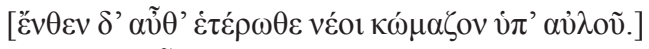

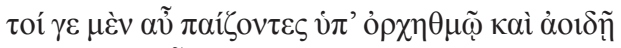

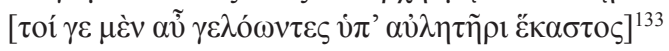

\footnotetext{
${ }^{128}$ Hom., Od., 7.106.

${ }^{129}$ Hom., Od., 7.115-6.

${ }^{130}$ Hom., Il. 18.493.

${ }^{131}$ Hom., Il. 18. 495.

${ }^{132}$ Hom., Il. 18.505.

${ }^{133}$ Hes., Scut. 275-83.
} 
Longe, o brilho de tochas acesas rodopiava

nas mãos de servas, viçosas de esplendor iam adiante, seguidas de coros dançantes, que com sonoras flautas lançavam a voz das suaves bocas. Ao redor quebrava o eco. Elas com liras conduziam coro amoroso. Aí no outro lado jovens festejavam com flautas, uns a brincarem com a dança e o canto, outros a rirem, cada um com o flautista. ${ }^{134}$

A literatura helenística retoma e revitaliza o procedimento e, nesse sentido, nas Argonáuticas de Apolônio de Rodes, na descrição da capa de Jasão, tem-se: ...Zñ $\theta$ os $\mu \dot{\varepsilon} v$

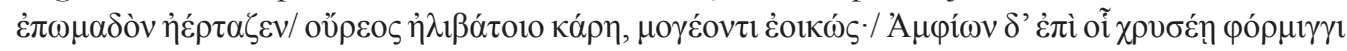

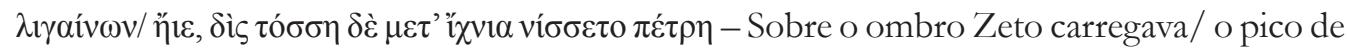
um abrupto monte como ombreiro;/ com ele Anfíon, co’áurea fórminge cantando/ e atrás tal rocha que dobrava de tamanho. ${ }^{135} \mathrm{Na}$ Eneida, Virgílio ao compor os quadros d'Ílion no templo de Juno em Cartago, falando das mulheres troianas assevera o gesto de contristação dessas mulheres, desenhando o som que reverbera de suas mãos espalmadas golpeando seus próprios peitos, diz o mantuano: Interea ad templum non aequae Palladis ibant/ crinibus Iliades passis peplumque ferebant, / suppliciter, tristes et tunsae pectora palmis - Nisso as ilíadas se dirigiam ao templo de Palas, / infesa Troia. Cabelos ao vento, de aspecto tristonho, / um belo manto lhe ofertavam; no peito com as mãos percutiam. ${ }^{136}$ Neste caso além da amplificação sensorial, por assim dizer, e excluindo o aspecto metalinguístico impresso à questão nos textos de Homero e Hesíodo - são orais - a visualização ocupa-se de uma dimensão patética que a cena evoca, de sorte que a amplificação dos sentidos na écfrase amplifica argumentativamente o $\pi \dot{\alpha} \theta$ os como efeito pretendido.

Em Filóstrato, o velho, inúmeros exemplos sinestésicos são apresentados no decurso de sua exploração da galeria de arte com seus jovens pupilos. Em Como, temos duas passagens interessantes. A primeira privilegiando o olfato e a segunda a audição, vejamos: a) "غ̇ं $\alpha \iota v \tilde{\omega}$

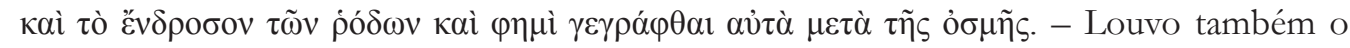

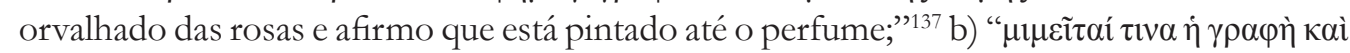

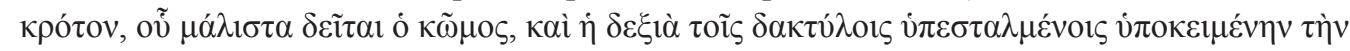

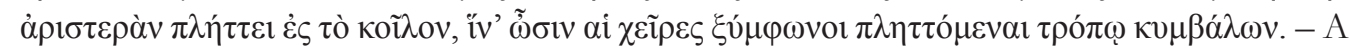
pintura imita de alguma forma o estrépito de que tanto precisa Como, e a mão direita, em punho, golpeia o oco da esquerda, para que as mãos assim golpeadas ressoem em uníssono à moda de címbalos." ${ }^{138}$ Assim como o odor das rosas é pintado pelo discurso, também o são o estrépito e o ressoar dos golpes da mão. Em Meneceu temos outro bom exemplo: “ópa

\footnotetext{
${ }^{134}$ Tradução de Jaa Torrano.

135 A.R., 1.738-41. Tradução de Vinícius Ferreira Barth.

${ }^{136}$ Virg., A.1.479-81.

${ }^{137}$ Philostr., Im. 1.2.4.5. Tradução de Rosângela Santoro de Souza Amato.

${ }^{138}$ Philostr., Im. 1.2.5.14-8.
} 


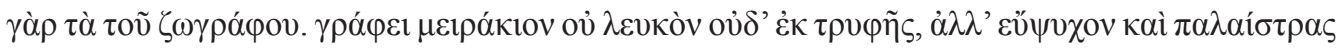

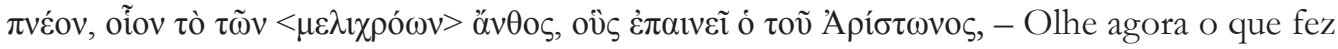
o pintor! Pinta o jovem não pálido e efeminado, mas corajoso e com o cheiro dos ginásios, bronzeado, como apraz ao filho de Áriston."

Assim, tanto o olhar periegemático que sustenta a écfrase, cuja dimensão radial amplia a captação de detalhes, como a exploração de cores e sentidos, tomados referencialmente ou em viés sinestésico, cuja aplicação amplifica as potencialidades discursivas descritivas de fazer ver e fazer sentir, são elementos que caracterizam de forma indene a écfrase, distinguindo-a da simples descrição referencial.

\section{Modernidade}

Koelb, reavaliando o trabalho de Webb (1999), informa que modernamente o conceito de écfrase reaparece no final do século XIX reduzido à descrição de obra de arte. Observa, porém, que os trabalhos referenciadores desta ideia, os de Bertrand e Bougot, dizem respeito às Imagines de Filóstrato, e, nesse sentido, o equivoco apenas reproduziria a compreensão que os séculos XV, XVI, XVII e XVIII já tinham a respeito da écfrase, de um lado, e dessa obra de Filóstrato, o velho, de outro. Efetivamente, embora esses dois classicistas tenham operado o engano no XIX, vale lembrar que Nicolau de Mira, o rétor, já acrescentara entre os tipos de écfrases, aquelas que se dedicariam à pintura, numa clara referência aos dois Filóstratos e à escultura, ao que parece indicando a obra de Calístrato. Porém, as duas estudiosas, Webb e Koelb, reiteram que foi Leo Spitzer, em seu artigo sobre "Ode on a Grecian Urn" de John Keats, o primeiro a disseminar o conceito reduzido no âmbito da Teoria Literária e do New Criticism. Spitzer afirma que:

It is first of all a description of an urn - that is, it belongs to the genre, known to Occidental literature from Homer and Theocritus to the Parnassians and Rilke, of the ekphrasis, the poetic description of a pictorial or sculptural work of art, which description implies, in the words of Théophile Gautier, "une transposition d'art," the reproduction through the medium of sensuously perceptible objects d'art (ut pictura poesis). ${ }^{139}$

Parece-me, entretanto, que entender que a modernidade apenas restringiu a écfrase semanticamente, fazendo-a prosperar somente como um conceito em sinédoque, de espécie por gênero, é equivocado uma vez que, modernamente observada, a écfrase teve suas possibilidades de uso ampliadas, a despeito de seu objeto ser restritivo, e isto está em absoluta coadunação aos novos acordos estético-doutrinais entre os quais estão, a meu ver, aqueles que supõem a representação da transcendência, da utopia - stricto sensu - em ampliação de sentido da ideia de sublime de Ps.-Longino, ou ainda, acordos que dão lugar à expressão linguístico-literária de um espaço-tempo, ou melhor, de dimensões temporais

${ }^{139}$ Spitzer (1955, p. 206-7). 
e espaciais não usuais ou incomuns. Assim tais possibilidades de uso da écfrase revestem de novos sentidos o mecanismo-procedimento retórico-poético para além da ortodoxia doutrinária antiga, absolutamente adequados aos novos tempos, longe, portanto, de uma restrição simples e supostamente limitadora. Assim se Leo Spitzer, ao pontificar a écfrase como descrição de obra de arte exclusivamente, pode ter limitado o objeto operado pela écfrase moderna, - e o fez - isto não significa que tal objeto artístico representa algo que é

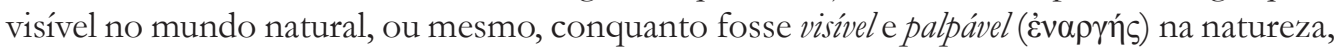
este seguramente poderia ou não estar sendo tomado denotativa ou referencialmente; mas, em caso negativo, como metáfora, hipérbole, prosopopeia e reificação, etc., retirando e afastando de si certo caráter protocolar de uma descrição meramente denotativa. Portanto, erro foi desconsiderar a normatização e a aplicação histórica do conceito, entendendo que a filiação ao procedimento transistórico ou obsequiando as claras e precisas referências clássicas de emulação, tendo sido observado Keats, pudesse lhe afetar as virtudes de puro sangue romântico ou de senhor de uma originalidade genial.

No entanto, ainda me debruçando sobre a restrição semântica da écfrase como descrição de obra de arte, há que se pensar não só em exemplos pragmáticos e doutrinários antigos, como também em autores dos séculos XV ao XVIII que continuadamente deram significativa relevância à relação entre poesia e pintura, expressa de três formas distintas, mas correlatas: a aplicação de conceitos da arte retórica à arte da pintura; a compreensão da arte da pintura como uma tradução visual ou figurativa de uma estória ou de um tema literário e o entendimento da écfrase em seu sentido estrito, isto é, descrição de obras visuais, ou ainda, a compreensão de que esta écfrase nada mais era do que a intermediação da literatura no entendimento da obra visual. Em qualquer uma dessas possibilidades o que posso notar é a presença do preceito horaciano do utpictura poesis redivivo. Nesse sentido, devemos entender a reconstrução moderna de écfrase como uma revalorização da arte romântica que rapta do renascimento e da antiguidade referências de erudição a fim de impor a sua arte "maior valor estético", logo afastando-a, em certa medida, do gênio inspirado e original e aproximando-a de referentes historicamente observáveis, legitimando auctoritates antigas.

Assim, o poema de Keats desnuda um sofisticado nível de atenção com o passado, ao repercutir certos procedimentos próprios das écfrases autônomas dos epigramas ecfrásticos e das imagines de Filóstrato, o velho ou de elementos estruturais contemplados por Homero e Virgílio. Seu nível de erudição de longe ultrapassa um vazio estético, estéril, antes atribuo a sua poesia contribuição relevante àquilo que pode ser considerada simples descrição de obra de arte, observada restritivamente. A urna grega de Keats - artefato absolutamente frequente em museus - muito além de ser uma tradução de um artefato em palavras construída referencialmente, constitui-se como marco interessante na série histórica de écfrases, dado que aponta conscientemente para uma função inolvidável e paradoxal: a vida e a morte em estreita relação com a arte, seja poesia, seja pintura. Mas isto transcende à simples confinidade entre elas; na verdade, revitaliza, no séc. XIX, o aforisma de Hipócrates, revivido por Sêneca: ars longa, nita bremis. Vale dizer que esta urna serve como depósito de cinzas de mortos, logo afeita à lembrança de quem já não está mais presente, de maneira que esta se 
compara à própria natureza da écfrase, pois que esta e aquela tornam presente algo ausente, a urna, o morto; a écfrase, a imagem. Enquanto sua forma, sua decoração, as pinturas que a compõem, associam-se, via écfrase, à ideia de perenidade; seu conteúdo é um morto, ou melhor, restos, sobras, vestígios de um morto, resguardado, encapsulado e imune à ação deletéria do tempo. Ademais é interessante o fato de que, ao compor sua descrição palpável, Keats vivifica suas imagens, as põe em movimento no tempo eterno, representando, a meu ver, a imortalidade que deve estar presente nas artes; entretanto, o poeta vai além, a própria urna é alguém personificado, afinal ela é thou...unravish'd bride of quietness, ou thou foster-child of silence. Mas deixemos Keats falar:

Thou still unravish'd bride of quietness,

Thou foster-child of silence and slow time,

Sylvan historian, who canst thus express

A flowery tale more sweetly than our rhyme:

What leaf-fring'd legend haunts about thy shape

Of deities or mortals, or of both,

In Tempe or the dales of Arcady?

What men or gods are these? What maidens loth?

What mad pursuit? What struggle to escape?

What pipes and timbrels? What wild ecstasy?

Heard melodies are sweet, but those unheard

Are sweeter; therefore, ye soft pipes, play on;

Not to the sensual ear, but, more endear'd,

Pipe to the spirit ditties of no tone:

Fair youth, beneath the trees, thou canst not leave

Thy song, nor ever can those trees be bare;

Bold Lover, never, never canst thou kiss,

Though winning near the goal yet, do not grieve;

She cannot fade, though thou hast not thy bliss,

For ever wilt thou love, and she be fair!

O poema inicia com apresentação do interlocutor thou, indicado como uma still unravish'd bride of quietness - ainda não-violentada noiva da mansidão, da quietude, da calma; uma filha de criação do silêncio e do lento tempo, historiadora silvestre que pode então expressar uma estória florida mais doce do que a rima, a poesia que é justamente a expressão do eu-poemático, já que a poesia a que se refere é our rbyme. Continua: What leaffring'd legend haunts about thy shape? - Mas que lenda de franja petalada assombra sobre tua forma? -, isto é, como esta noiva inviolada da mansidão, filha de criação do silêncio e do lento tempo é uma historiadora silvestre? Como alguém é capaz de formular narrativas tão qualificadas (floridas) que superam a própria poesia, pois a desvela, a revela, a interpreta - $\dot{\varepsilon} \rho \eta \eta v \varepsilon v \omega ?$ A ideia de

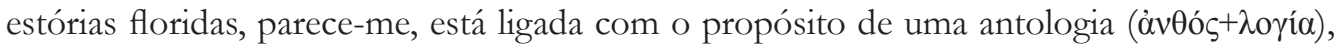
de florilégio que, nesse sentido, não só une as cinco estrofes do poema como pode ser remetida à forma epigramática dos livros II e III da Antologia Palatina que contém epigramas 
ecfrásticos, como às próprias coleções de quadros dos dois Filóstratos e de Calístrato. Assim Keats marca, ao meu ver, sua posição na série histórica das écfrases, apresenta "suas amizades poéticas". ${ }^{140}$ Retomo o poema. Resta saber que forma é esta: deities? mortals? Both? - Deidades? Mortais? Ambos? Onde ela está? Em Tempe? Na Arcádia? Que homens e deuses são estes? Que virgem relutante é esta? Que louca perseguição? Que luta para fugir? Que flautas e tamboretes? Que selvagem êxtase? Parece claro que esta estrofe apresenta o suporte de uma narrativa que traz em si eventos enigmáticos que devem ser esclarecidos pelo observador/leitor, um enunciatário experto que os vê e os lê, de forma que o faz com os olhos incorpóreos da $\varphi \alpha v \tau \alpha \sigma i ́ \alpha$ a partir da leitura do $\lambda o ́ \gamma o \varsigma$, da écfrase poética. Assim, as imagens são convertidas em linguagem verbal pelo poeta sem que a natureza visual as abandone. Ainda é importante ressaltar que Keats em caminho inverso a Platão, e em absoluto acordo com os rétores e sofistas antigos - principalmente os da segunda sofística -, vê nos procedimentos imagéticos valor e não déficit visto que os valoriza explicitamente.

A atenção do leitor/observador, nos moldes apontados por Goldhill, como já vimos, neste caso é dupla: tanto pode ser a de um olhar perplexo e admirado, talvez, maravilhado $(\theta \alpha v \mu \alpha ́ \zeta \omega / m i r a r i)$ que tenta desvendar o reconhecimento da sua própria condição, logo, da condição humana, de sua natureza limitada e precária diante da arte, ou, simplesmente, diante do duplo que nos une, a todos nós: vida e morte; como pode ser a de um olhar reflexivo e atento, operado pelo observador dos epigramas ecfrásticos, silente e transfixado, ocupado em desvendar enigmas trazidos à luz em forma de poesia e de relevo de uma urna grega que fala; observador este que diante do inefável desvendado e principalmente revelado ( $\tau$ ò $\delta \eta \lambda$ ov́ $\mu \varepsilon v o v$ ),

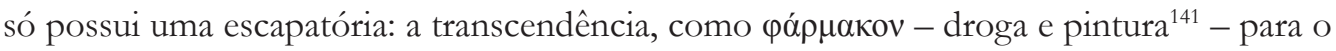
seu spleen, afinal o que poderia produzir mais melancolia do que a inesgotável eternidade? That leaves a heart high-sorrowful and cloy'd, / A burning forehead, and a parching tongue.

Isso é o que se confirma na segunda estrofe, já que as melodias ouvidas a partir da poesia, provavelmente, são doces, mas mais doces são as inaudíveis porquanto esculpidas, cinzeladas, pintadas...-como já vimos a importância das sinestesias na écfrase - Heard melodies are sweet, but those unheard / Are sweeter...Donde, exorta as flautas a soar, flautas igualmente animadas já que são ye: therefore, ye soft pipes, play on - Vós, suaves flautas, portanto, folgai! Entretanto não para os ouvidos reais, mas para o sensual ear-ouvido sensível ou sensual - são possibilidades - mas para o ouvido encarecido, connaisseur, experto, para aquele que conhece a música sem a música ... Pipe to the spirit ditties of no tone - Flauta para as cantigas da mente sem música. O jovem músico não pode abandonar sua flauta sob as árvores, tampouco as árvores podem perder suas folhas - Fair youth, beneath the trees, thou canst not leave/ Thy song, nor ever can those trees be bare. Junto com o flautista - Virgílio bucólico e Homero de Fêmio ${ }^{142}$

\footnotetext{
${ }^{140}$ Algo me leva a crer que Les Fleurs du Mal retomará anos mais tarde esta mesma ideia de coleção poética, filtrada sob a égide da poética do XIX. Baudelaire nasce no ano da morte de Keats em 1821, As Flores do Mal são publicadas em 1851.

${ }^{141}$ Traduções possíveis para o termo.

${ }^{142}$ Hom., Od. 22.
} 
e de Demódoco ${ }^{143}$ são referências importantes - tem-se a imutabilidade do quadro que permanece vivo e eterno sempre, o que é confirmado pela terceira estrofe:

Ah, happy, happy boughs! that cannot shed

Your leaves, nor ever bid the Spring adieu;

And, happy melodist, unwearied,

For ever piping songs for ever new;

More happy love! more happy, happy love!

For ever warm and still to be enjoy'd,

For ever panting, and for ever young;

All breathing human passion far above,

That leaves a heart high-sorrowful and cloy'd,

A burning forehead, and a parching tongue.

É digno de nota o uso do advérbio de tempo “ever", positiva e negativamente utilizado, denotando a perenidade dos elementos compósitos apresentados, isto é, as folhas que nunca perdem o viço e que não temem a passagem das estações - a idade do ouro -, o cantor que sempre renova seu canto, o amante sempre desejoso mais do que feliz sempre, como um Odisseu que astuciosamente não perdeu a esperança. Nesse sentido, a estrofe interage diretamente com a Odisseia e com a Ilíada. Lembra tanto o canto da memória coletiva, como os jardins e os pomares da casa de Alcino. Tomemos agora as duas últimas estrofes:

Who are these coming to the sacrifice?

To what green altar, $\mathrm{O}$ mysterious priest,

Lead'st thou that heifer lowing at the skies,

And all her silken flanks with garlands drest?

What little town by river or sea shore,

Or mountain-built with peaceful citadel,

Is emptied of this folk, this pious morn?

And, little town, thy streets for evermore

Will silent be; and not a soul to tell

Why thou art desolate, can e'er return.

O Attic shape! Fair attitude! with brede

Of marble men and maidens overwrought,

With forest branches and the trodden weed;

Thou, silent form, dost tease us out of thought

As doth eternity: Cold Pastoral!

When old age shall this generation waste,

Thou shalt remain, in midst of other woe

Than ours, a friend to man, to whom thou say'st,

"Beauty is truth, truth beauty, - that is all

Ye know on earth, and all ye need to know."

${ }^{143}$ Hom., Od. 8. 
$\mathrm{Na}$ quarta estrofe, Keats apresenta a descrição da urna acrescentando verbos de movimento como que animando a cena, isto é, fazendo com que os elementos representados passassem a agir: Who are these coming to the sacrifice? - Quem são estes vindo para o sacrifício? O mysterious priest, / Lead'st thou that heifer lowing at the skies - Ó misterioso sacerdote, conduz tua novilha berrando aos céus. Nos dois primeiros versos temos a assistência da cena - Who are these? No terceiro e quarto versos, têm-se o sacerdote e seu sacrifício - uma rês, uma virgem... afinal caminha enfeitada com guirnaldas acetinadas nos flancos. Quem sabe é uma virgem? - that heifer lowing at the skies. Entretanto, é digno de nota que o poeta circunscreve sua écfrase no âmbito da periegese, não só pelo afluxo de uma população que vai caminhando assistir ao sacrifício como também pela posição assumida pelo sacerdote que conduz seu

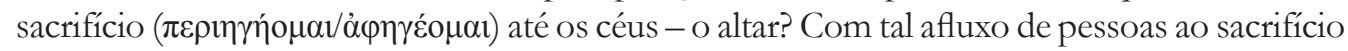
a pequenina cidade está vazia. As referências à própria noção de écfrase é aqui exposta, já que tal procissão pode ser ligada a condição do discurso periegemático.

O fechamento do poema encaminha finalmente a reflexão central. A forma ática é exortada, apontando para homens e jovens de mármore, acompanhados da relva e das folhagens. Keats retoma a ideia de silêncio das imagens e sua capacidade de nos provocar,

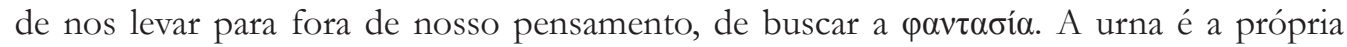
eternidade. A juventude que a produz como poesia irá envelhecer e morrer, enquanto a arte será sempre eterna. Daí finaliza: Beauty is truth, truth beauty, — that is all/ Ye know on earth, and all ye need to know."

\section{ConClusões}

Uma questão, por fim, que deve ser observada diacronicamente é qual motivo teria feito o conceito retórico-poético de écfrase mais amplo se restringir, limitar-se à descrição de obra de arte. Quatro vetores somados parecem responder essa questão semântica:

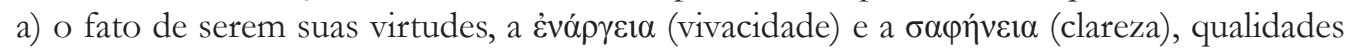
especialmente visuais, ou melhor, que expressam visualmente algo verbalmente lido ou ouvido; b) a reincidência de descrições de objetos artísticos - lato sensu - na série histórica de écfrases interventivas em gêneros continentes, a saber, os escudos de Aquiles, Héracles, Eneias e de Aníbal (cinzelamento), o palácio de Alcino, o templo de Apolo (arquitetura), as pinturas do templo de Juno (pintura), os mantos de Jasão e de Tétis, a tapeçaria da tenda (tecelagem); c) Filóstrato, o velho, rétor com obra vária e reconhecida, cujo opúsculo Еikóveৎ ou Imagines - duas coleções de descrições de quadros - teria assanhado os prudentes do Renascimento a tomá-las, écfrases, não só como modelo de suas pinturas, mas também como louvor às antigas autoridades, autores de quadros perdidos; d) a relação entre os epigramas ecfrásticos e as obras de estatuária.

Filóstrato, o velho, de um lado e Paulo Silenciário, de outro, são responsáveis por um categoria intermediária de écfrases (no sentido antigo) de obras de arte e de arquitetura. Uma diferença parece-me indiscutível: o primeiro opera um modelo imaginário, uma

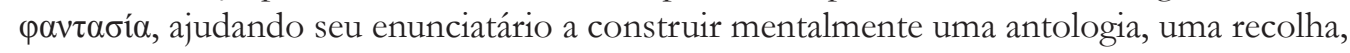


um florilégio de imagens - verbais ou não - que pertencem a memória coletiva desses antigos, como se pudéssemos ter uma série de quadros compondo a memória partilhada, em forma de pequenos discursos epidíticos; já o segundo ocupa-se em produzir poesia tendo como objeto um lugar sagrado concreto e existente, fazendo que o leitor que não conhece a catedral reproduza mentalmente a sua própria Santa Sofia em $\varphi \alpha v \tau \alpha \sigma i ́ \alpha$ ou fazendo que aquele que a conhece pessoalmente amplifique suas possibilidades de transcendência diante da grandeza da obra de Deus. Os quadros de Filóstrato reproduzem elementos dos lugares da memória partilhada, como operação intelectual e inteligível, a Écfrase da Hagia Sophia de Silenciário reproduz em princípio o visível, o concreto, como operação sensível a fim de fazer que o mundo concreto converta-se em lugar transcendente, amplificando, portanto, a magnificência da arquitetura em nome das virtudes que presenta. A galeria de Filóstrato converte a pertença coletiva em produto colecionável da memória letrada e iconográfica, fonte da qual Keats pode ter muito bem bebido.

Assim, creio que para estudarmos a écfrase hoje em dia, seja ela antiga, moderna ou contemporânea significa não abrir mão de uma visada retrospectiva dela, de um lado, e prospectiva dela e sobre ela, de outro, a fim de que possamos redefini-la de acordo com seus critérios transistóricos. Ainda que Webb tenha argumentado que a restrição semântica imposta à écfrase seja em grande parte obra de Spitzer em 1955, Zeitlin mais recentemente aponta que o fenômeno é antigo, já que as écfrases interventivas são de objetos manufaturados artisticamente e, além disso, a relação entre imagem e palavras é uma preocupação que pode ser mapeada pelo menos desde Simônides, citado por Plutarco, ao propor que a pintura é a poesia muda e a poesia é a pintura que fala. Isto sem falar do Horácio da Ars, v.361: ut pictura poesis, como a pintura a poesia.

Heffernan, em seu trabalho de 1991, acerca das relações entre écfrase e representação, apresenta uma boa síntese acerca das questões que cercam a écfrase modernamente. Argumenta inicialmente que apesar de a écfrase ser sistematicamente discutida em vários encontros acadêmicos, "this ancient term is still struggling for modern recognition". Gravemente vaticina que poucos são os estudiosos que se ocupam da écfrase, entretanto isso não significa que os trabalhos que envolvem a relação literatura e artes visuais sejam poucos, mas significa sim que quase ninguém modernamente vem usando o termo, nem mesmo aqueles que se envolveram com a discussão do poema de Keats, estudado por Spitzer. Diante desta situação caótica "desenhada" pelo crítico, porém, ele acredita que se deve entendê-la como modo literário e, nesse sentido, apresenta a teoria de Murray Krieger de 1967, que discute a écfrase como "a general principle of poetics, asserted by every poem in assertion of its integrity", de sorte que este eleva a écfrase de um tipo de literatura para um princípio literário, fazendo com que "the plastic, spatial object of poetic relationships which must be superimposed upon literature's turning world to 'still' it." Fato para o qual espero ter contribuído. 


\section{REFERÊNCIAS}

AMATO, R. S. S. Amores e outras imagens de Filostrato. São Paulo: Fundação Bienal; Hedra, 2012.

BAGOLIN, L. Ékphrasis no Segundo Comentário de Lorenzo Ghiberti. Letras Clássicas, v. 18, n. 1, p. 51-72, 2014. DOI: 10.11606/issn.2358-3150.v18i1p51-72.

BAILLY, A. Dictionnaire Grec-Français. Paris: Hachette, 1984.

BAL, M. Narratology: Introduction to the Theory of Narrative. 3rd ed. Toronto: University of Toronto Press, 2009.

BARBETTI, C. Ekphrastic Medieval Visions: A New Discussion in Interarts Theory. New York: Palgrave Macmillan, 2011.

BARTH, V. F. O Canto I das Argonáuticas de Apolônio de Rodes. 2013. Dissertação (Mestrado) -UFPR, Curitiba, 2013.

BARTHES, R. "L'effet de reel" in Communications, 11. Recherches sémiologiques le vraisemblable: 84-9, 1968. DOI: 10.3406/comm.1968.1158. Acesso em: 21 jan. 2017.

BECKER, E. Paulus Salentiarius Descriptio S. Sophiae et Ambonis. Ex Recognitione Immanuelis Bekkeri in Nierbuhrii, B. G. Corpus Scriptorum Historiae Byzantinae: 3-48, 1837.

BENEDIKTSON, D. T. Literature and the Visual Arts in Ancient Greece and Rome. Norman: University of Oklahoma Press, 2000.

BERTRAND, E. Un Critique d'art dans l'antiquité: Philostrate et son école. Paris: E. Thorin, 1882.

BORGES, J. L. "Del rigor en la ciencia" in Historia universal de la infamia, 1946.

BOUGOT, A. Philostrate l'ancien: une galérie antique. Paris: Librairie Renouard, 1881.

BOWIE, E. Philostratus: The Life of a Sophist. In: BOWIE, E.; ELSNER, J. (eds.). Philostratus. Cambridge: Cambridge University Press, 2009, p. 19-32.

BOWIE, E.; ELSNER, J. (eds.). Philostratus. Cambridge: Cambridge University Press, 2009.

BRADLEY, M. Colour as Synaesthetic experience in Antiquity. In: BUTLER, S.; PURVES, A. (eds.). Synaesthesia and the Ancient Senses. Durhan: Acumen, 2013, p. 127-90.

CALVINO, I. Por que Ler os Clássicos. São Paulo: Cia. das Letras, 1994.

CHINN, C. Before Your Very Eyes: Pliny Epistulae 5.6 and the Ancient Theory of Ekphrasis. CPh, v. 102, n. 3, p. 265-80, 2007. DOI:10.1086/529472.

COSTA E SILVA, B. A narrativa da écfrase no Idílio I de Teócrito e na Europa de Mosco. In: RODRIGUES, F. et alii. Helenismo. São Paulo: Humanitas, 2016, p. 115-29.

DIBBERN, C. O escudo de Aníbal: Punica 2.395-456. Letras Clássicas, v. 18, n. 1, p. 127-37, 2014. DOI: 10.11606/issn.2358-3150.v18i1p127-137. 
DUARTE, A. Cena e cenografia no Íon de Eurípides. Letras Clássicas, v. 18, n. 1, p. 35-50, 2014. DOI: 10.11606/issn.2358-3150.v18i1p35-50.

DUBEL, S. Ekphrasis et enargeia: la description antique comme percurs. In: LÉVY, C.; PERNOT, L. (org.). Dire l'Evidence. Paris: L' Harmattan, 1997, p. 249-64.

ELSNER, J. The Genres of ekphrasis. In: ELSNER, J. (ed.). The Verbal and the Visual: Cultures of Ekphrasis in Antiquity. Ramus, v. 31, p. 1-18, 2002. DOI: 10.1017/S0048671X00001338.

ELSNER, J. A Protean Corpus. In: BOWIE E.; ELSNER J. (eds.). Philostratus. Cambridge: Cambridge University Press, 2009, p. 3-18.

FELTEN, J. (ed.) Nicolai Progymnasmata. Leipzig: Teubner, 1913. [Rhetores Graeci 11].

FOWLER, D. Narrate and Describe: The Problem of Ekphrasis. JRS, v. 81, p. 25-35, 1991. DOI:10.2307/300486.

FRIEDLAENDER, P. Johannes von Gaza und Paulus Silentiarius: Kunstbeschreibungen justinianischer Zeit. Leipzig: Teubner [=Nachdruck: Hildesheim 1969], 1912.

GENETTE, G. Figures of Literary Discourse. Trans. A. Sheridan. New York: Columbia University Press, 1982.

GIBSON, C. A. Libanius's progymnasmata: model exercises in Greek prose composition and rhetoric. Translated with an introduction and notes by C. A. Gibson. Atlanta: Society of Biblical Literature, 2008.

GOLDHILL, S. What Is Ekphrasis For? CPh, v. 102, n. 1, p. 1-19, 2007.

HALM, K. Praeexercitamina Priciani Grammatici ex Hermogene versa. In: Rhetores Minores. Lipsiae: in aedibus B. G. Teubneri, 1863, p. 551-60.

HANSEN, J. A. Categorias epidíticas da ekphrasis. Revista USP, v. 71, p. 85-105, 2006.

HARDEN, S. J. Eros Through the Looking-Glass? Erotic Ekphrasis and Narrative Structure in Moschus' Europa. Ramus, v. 40, n. 2, p. 87-105, 2011. DOI: 10.1017/S0048671X00000357.

HARLOE, K. Allusion and ekphrasis in Winckelmann's. Paris description of the Apollo Belvedere. CCJ, v. 53, p. 229-52, 2007.

HEFFERNAN, J. A. Ekphrasis and Representation. New Literary History, Roblings: Art, Criticism, Genre, v. 22, n. 2, p. 297-316, 1991.

KENNEDY, G. A. Progymnasmata. Greek Textbooks of Prose Composition and Rhetoric. Aelius Theon; Hermogenes; Aphtonius The Sophist; Nicolaus The Sophist. Atlanta: Society of Biblical Literature, 2003.

KOELB, J. H. The poetics of description: imagined places in European literature. New York; Basingstoke: Palgrave Macmillan, 2006. 
KOSSOVITCH, L. La Descontinuité dans l'Histoire de l'Art. In: GALARD, J. (org.). Ruptures: de la Descontinuité dans la Vie Artistique. Paris: École Nationale Supérieure des Beaux-Arts/ Musée du Louvre, 2002, p. 303-39.

KRIEGER, M. Ekphrasis and the Still Movement of Poetry; or, Laokoön Revisited. In: McDOWELL, F. P. W. (ed.). The Poet as Critic. Evanston. The Play and Place of Criticism. Baltimore: Johns Hopkins University Press, 1967, p. 263-88.

LAUSBERG, H. Elementos de Retórica Literária. Tradução, prefácio e aditamentos de R. M. Rosado Fernandes. 2. ed. Lisboa: Fund. Calouste Gulbenkian, 1972.

LAUSBERG, H. Manual de Retórica Literaria. v. I-III. Versión española de José Pérez Riesco. Madrid: Gredos, 1991.

LS - Lewis, C. T.; SHORT, C. A Latin Dictionary. Oxford: At Clarendon Press, 1987.

LSJ - Lidell, H. G.; SCOTT, R.; JONES, H. S. A Greek-English Lexicon. Oxford: At Clarendon Press, 1977.

LOURENÇO, F. Odisseia. Homero. São Paulo: Cia. das Letras, 2011.

LOURENÇO, F. Ilíada. Homero. São Paulo: Cia. das Letras, 2013.

LUKACS, G. Writer and Critic and other Essays. Trans. A. Kahn. London: Merlin, 1978.

MACRIDES, R.; MAGDALINO, P. The architecture of ekphrasis: construction and context of Paul the Silentiary's poem on Hagia Sophia. BMGS, v. 12, p. 47-82, 1988.

MASON, H. C. Jason's Cloak and the shield of Heracles. Mnemosyne, v. 69, p. 183-201, 2016. DOI: $10.1163 / 1568525 \mathrm{X}-12341830$.

MARTINHO, M. À propos des différences entre les Praeexercitamina de Priscien et les Progymnasmata du Ps.-Hermogène. In: BARATIN, M.; COLOMBAT, B.; HOLTZ, L. (eds.). Priscien: Transmission et refondation de la grammaire, de l'antiquité aux modernes. Turnhout: Brepols Publishers, [Studia Artistarum, 21], 2009, p. 395-410.

MARTINHO, M. Acerca das Diferenças Doutrinais entre os Praeexercitamina de Prisciano e os Progymnásmata do Ps.-Hermógenes. In: FLORES-JÚNIOR, O.; MARTINHO, M.; RENNÓ ASSUNÇÃO, T. (org.). Ensaios de retórica antiga. Belo Horizonte: Tessitura, 2010, p. 269-89.

MARTINS, P. Eneias se reconhece. Letras Clássicas, v. 5, n. 1, p. 143-157, 2001. DOI: 10.11606/ issn.2358-3150.v0i5p143-157 [= Martins (2013, p. 48-68)].

MARTINS, P. Desafios da Écfrase. In: RODOLPHO, M. Écfrase e Evidência nas Letras Latinas: Doutrina e Práxis. São Paulo: Humanitas, 2012, p. 13-23.

MARTINS, P. Pictura tacens, poesis loquens. Limites da Representação. Tese (Livre-Docência) Departamento de Letras Clássicas e Vernáculas da Universidade de São Paulo, 2013.

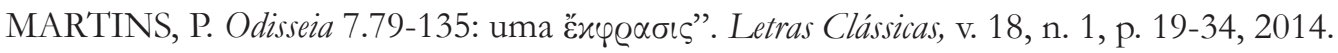
DOI: 10.11606/issn.2358-3150.v18i1p19-34 [= Martins (2013, p. 32-46)]. 
MARTINS, P. Vertentes do retrato romano no final da República e no início do Principado. Cadernos de Pesquisa Histórica, Uberlândia, UFU, v. 27, n. 2. p. 13-38, $2014 \mathrm{~b}$.

MATTIACCI, S. Quando L'immagine ha Bisogno della Parola: Riflessioni sulla Poetica dell'ekphrasis nell'epigramma latino. Prometheus, v. 39, p. 207-26, 2013.

MERRIAM, C. U. An Examination of Janson's Cloak (Apollonius Rhodius, Argonautica 1.730-68). Scholia, v. 2, p. 69-80, 1993.

NICOLAI, R. L'ekfrasis, Una Tipologia Compositiva dimenticata dalla Critica Anticae dalla Moderna. Aion (filol.), v. 31, p. 29-45, 2009.

NOGUEIRA, É. Verdade, contenda e poesia nos Idílios de Teócrito. Tese (Doutorado) - Faculdade de Filosofia, Letras e Ciências Humanas, Universidade de São Paulo, São Paulo, 2012. DOI:10.11606/T.8.2012.tde-06112012-125428. Recuperado em 2016-12-20, de www.teses. usp.br.

NUNES, C. A. Eneida. Virgílio. Organizada por João Angelo Oliva Neto. São Paulo: 34 Editora, 2013.

OLD - Glare, P. G. W. Oxford Latin Dictionary. Oxford: At Clarendon Press, 2006.

OLIVA NETO, J. A. Écfrase da Vila de Plínio na Túscia (Plínio, o Jovem, Livro 5, Epístola 6: comentário, tradução e notas). Letras Clássicas, v. 19, n. 1, p. 181-95, 2015. DOI: 10.11606/ issn.2358-3150.v19i1p181-195.

ORTEGA, N. R. "Ut Pictura Poesis": Ekphrasis in the Seventeenth Century. In: BACA, M.; ORTEGA, N. R. (orgs.). Pietro Mellinis Inventory in Verse, 1681, 2016. http:/ / www.getty.edu/ research/mellini/essay/ekphrasis. Acesso em: 27 dez. 2016.

PATILlON, M.; BOLOGNESI, G. (eds.). Aelius Théon, Progymnasmata. Éd. Patillon, M. et Bolognesi, G. Paris: Les Belles Lettres, 1997.

PAYNE, M. Ecphrasis and Song in Theocritus' Idyll 1. GRBS, v. 42, p. 263-87, 2001.

PETERS, F. E. Termos Filosóficos Gregos. Trad. Beatriz Rodrigues Barbosa. 3. ed. Lisboa: Fundação Calouste Gulbenkian, 1977.

PUTNAM, M. C. J. Virgil's Epic Designs. Ekphrasis in the Aeneid. New Haven: Yale University Press, 1998.

RABE, H. (ed.). Hermogenis opera. Hermogenes Rhet., Progymnasmata. Leipzig: Teubner, 1969.

RLM - Halm, K. Rhetores Latini Minores. Ex Codicibus Maximam Partem Primum Adbibitis. Emendabat Carolus Halm. Lipsiae: In Aedibus B. G. Teubneri, 1863.

RODOLPHO, M. Écfrase e Evidência nas Letras Latinas: Doutrina e Práxis. São Paulo: Humanitas, 2012. 
RODOLPHO, M. Écfrase e evidência. Letras Clássicas, v. 18, n. 1, p. 94-113, 2014. DOI: 10.11606/issn.2358-3150.v18i1p94-113.

ROSAND, D. Ekphrasis and the Generation of Images. Arion, v. 1, n. 1, p. 61-105, 1990.

SEBASTIANI, B. B. História Pragmática de Políbio. Tradução dos Livros I-VI. Introdução e Notas. São Paulo: Perspectiva, 2016.

SHAPIRO, H. A. Jason’s Cloak. TAPhA, v. 110, p. 263-86, 1980.

SOARES, M. T. M. Ekphrasis e Enargeia na Historiografia de Tucídides e no Pensamento Filosófico de Paul Ricoeur. Talia Dixit, v. 6, p. 1-23, 2011.

SPENGEL, L. (ed.). Rhetores Graeci, vol. 2. Aelius Theon Rhet., Progymnasmata. Leipzig: Teubner, 1966.

SPITZER, L. The "Ode on a Grecian Urn," or Content vs. Metagrammar. Comparative Literature, v. 7, n. 3, p. 203-25, 1955. DOI:10.2307/1768227.

SQUIRE, M. Ecphrasis: Visual and Verbal Interactions in Ancient Greek and Latin Literature. In: Oxford Handbooks Online. Scholary Research Reviews, 2015. DOI: 10.1093/ oxfordhb/9780199935390.013.58.

STEWART, P. Statues in roman society. Representation and response. Oxford: Oxford University Press, 2003.

SWAIN, S. Culture and nature in Philostratus. In: BOWIE, E.; ELSNER, J. (eds.). Philostratus. Cambridge: Cambridge University Press, 2009, p. 33-48.

TORRANO, Jaa. O escudo de Héracles de Hesíodo. Tradução de Jaa Torrano, segundo o texto de F. Solmsen. Hypnos, v. 5/6, p. 185-221, 2000.

WERNER, E. Imagens tecidas em verso: A representação do mito de Ariadne no carmen LXIV de Catulo. Letras Clássicas, v. 19, n. 1, p. 162-80, 2016. DOI: 10.11606/issn.2358-3150. v19i1p162-180.

WHITBY, M. The occasion of Paul the Silentiary's Ekphrasis of S. Sophia. CQ, v. 35, n. 1, p. 215-28, 1985. DOI: 10.1017/S0009838800014695.

ZANCHETTA, R. Écfrase como exemplo de pintura. Letras Clássicas, v. 18, n. 1, p. 114-126, 2014. DOI: 10.11606/issn.2358-3150.v18i1p114-126

ZEITLIN, F. I. Figure: Ekphrasis. Greece \& Rome, v. 60, p. 17-31, 2013. DOI:10.1017/ S0017383512000241.

Recebido em: 24 de fevereiro de 2017 Aprovado em: 15 de março de 2017 